\title{
The Mediterranean Sea we want
}

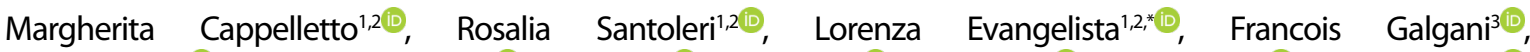

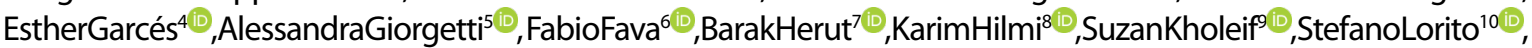

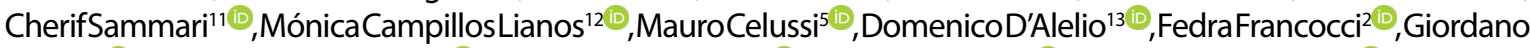

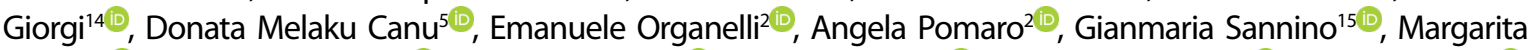

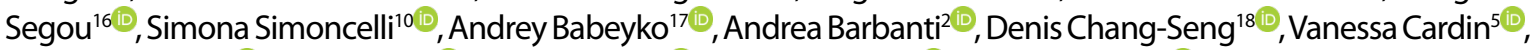

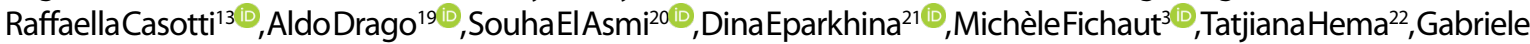

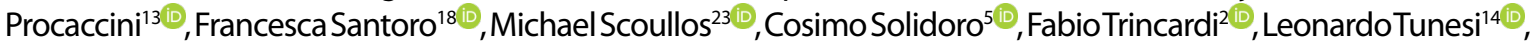

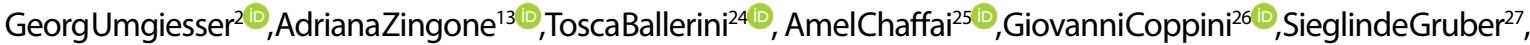

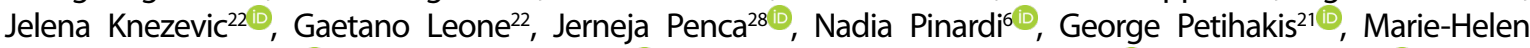
Rio $^{29}$, Mohamed Said ${ }^{9}$, Zacharias Siokouros ${ }^{30}$, Abdellah Srour $^{31}$, Maria Snoussi ${ }^{32}$, $^{-}$, Joaquín Tintoré ${ }^{33}$, Vassiliki $^{-}$

$$
\text { Vassilopoulou }{ }^{34} \text {, Marco Zavatarelli6(i) }
$$

${ }^{1}$ Commissione Oceanografica Italiana - COI (Piazzale Aldo Moro 7 - 00185 - Roma - Italy)

${ }^{2}$ Consiglio Nazionale delle Ricerche - CNR (Piazzale Aldo Moro 7 - 00185 - Roma - Italy)

${ }^{3}$ Institut Français de Recherche pour l'exploitation de la mer - IFREMER, Centre de Bretagne (MF)(1625 Route de Sainte-Anne CS10070 - 28280 PLOUZANE - France \& Station de Bastia - Corsica (FG)

${ }^{4}$ Institut de Ciencies del Mar (CSIC - 37-49 Passeig Marítim de - 08003 - Barcelona - Spain)

${ }^{5}$ Instituto Nazionale di Oceanografia e di Geofisica Sperimentale - OGS (Borgo Grotta Gigante 42/c - 34016 Sgonico - Trieste - Italy)

${ }^{6}$ Universita di Bologna (Via Terracini 28 - 40131 - Bologna - Italy)

${ }^{7}$ Israel Oceanographic and Limnological Research (Haifa - 3108001 - Israel)

${ }^{8}$ Institut National de Recherche Halieutique, Centre Régional de Casablanca (Bd Sidi Abderrahman Ain Diab - Casablanca - Marocco)

${ }^{9}$ National Institute of Oceanography and Fisheries (3 Aben Mahassen Street - Moharem Bay - Alexandria - Egypt)

${ }^{10}$ Instituto Nazionale Di Geofisica e Vulcanologia - INGV (Via di Vigna Murata, 605 - 00143 Roma - Italy)

${ }^{11}$ Institut National des Sciences et Technologies de la Mer (28 Rue du 2 mars 1934 - 2035 - Tunisia)

${ }^{12}$ Instituto Espanol de Oceanografia - IEO (Calle del Corazón de María, 8 - 28002 Madrid - Spain)

${ }^{13}$ Stazione Zoologica Anton Dohrn - SZN (Villa Comunale, 80121 - Napoli - Italy)

${ }^{14}$ Istituto Superiore per la Protezione e la Ricerca Ambientale - ISPRA (Via Vitaliano Brancati 48 - 00144 Roma - Italy)

${ }^{15}$ Agenzia nazionale per le nuove tecnologie, l'energia e lo sviluppo economico sostenibile - ENEA (Lungotevere Thaon di Revel, 76 - 00196, Roma - Italy)

${ }^{16}$ British Geological Survey BGS (Nicker Hill, Keyworth - Nottingham NG12 5GG - England - UK)

${ }^{17}$ Deutsches GeoForschungsZentrum - GFZ (Telegrafenberg - 14473 Potsdam - Germany)

${ }^{18}$ Intergovernmental Oceanographic Commission of UNESCO (7, place de Fontenoy - 75732 Paris cedex 07 - France)

${ }^{19}$ Physical Oceanography Research Group - Dept. of Geosciences, University of Malta (Msida MSD 2080 - Malta)

${ }^{20}$ Regional Activity Centre for Specially Protected Areas - SPA/RAC (RR21, Tunis - Tunisia)

${ }^{21}$ European Global Ocean Observing System - EuroGOOS AISBL, (29 Rue Vautier - 1000 Brussels - Belgium)

${ }_{22}$ United Nations Environment Programme / Coordinating Unit for the Mediterranean Action Plan - Barcelona Convention Secretariat (48, Vassileos Konstantinou Ave. - 11635 Athens - Greece)

${ }^{23}$ Mediterranean Information Office for Environment, Culture and Sustainable Development (Kirristou 12 - Athina 10556 - Greece)

${ }^{24}$ Expédition MED (4 allée des Avettes - 56230, Questembert - France)

${ }^{25}$ Innovation House Consulting(C) Sarl (Rte EL ain Km 2.5 - PO BOX 66 - 3051 Sfax-Tunisia)

${ }^{26}$ Centro Euro-Mediterraneo sui Cambiamenti Climatici - CMCC (Via Augusto Imperatore 16 - I-73100 Lecce - Italy)

${ }^{27}$ European Commission, DG Research and Innovation - SDME (2/2 B-1049 Brussels - Belgium)

${ }^{28}$ Euro-Mediterranean University (Kidričevo nabreje 2 - 6330 Piran- Slovenia)

${ }^{29}$ European Space Agency - ESRIN (Via Galileo Galilei, 1 - 00044 Frascati - Roma - Italy)

Submitted: 15-Mar-2021

Approved: 13-Aug-2021

Editor: Rubens M. Lopes

Associate Editor: Alexander Turra 
${ }^{30}$ Cyprus Marine and Maritime Institute - CMMI (Vasileos Pavlou Square 13 - Larnaca 6023 - Cyprus)

${ }^{31}$ General Fisheries Commission for the Mediterranean (Via Vittoria Colonna, 1 - 00193 - Roma - Italy)

${ }^{32}$ Mohammed V University (B.P: 1014 - Agdal PO Box 554 - Rabat - Chellah - Rabat - Michlifen Street, 3 - Morocco)

${ }^{33}$ Balearic Islands Coastal Observing and Forecasting System - SOCIB (Parc Bit - Naorte - Bloc A 2º. pta. 3 - 07121 - Palma de Mallorca - Spain)

${ }^{34}$ Hellenic Centre for Marine Research - HCMR (Athinon - Souniou Ave (46.7th km) - Anavyssos - 19013 - Greece)

* Corresponding author: lorenza.evangelista@cnr.it

\section{Abstract}

This paper presents major gaps and challenges for implementing the UN Decade of Ocean Science for Sustainable Development (2021-2030) in the Mediterranean region. The authors make recommendations on the scientific knowledge needs and codesign actions identified during two consultations, part of the Decade preparatory-phase, framing them in the Mediterranean Sea's unique environmental and socio-economic perspectives. According to the'Mediterranean State of the Environment and Development Report 2020' by the United Nations Environment Programme Mediterranean Action Plan and despite notable progress, the Mediterranean region is not on track to achieve and fully implement the Sustainable Development Goals of Agenda 2030. Key factors are the cumulative effect of multiple human-induced pressures that threaten the ecosystem resources and services in the global change scenario. The basin, identified as a climate change vulnerability hotspot, is exposed to pollution and rising impacts of climate change. This affects mainly the coastal zones, at increasing risk of extreme events and their negative effects of unsustainable management of key economic assets. Transitioning to a sustainable blue economy is the key for the marine environment's health and the nourishment of future generations. This challenging context, offering the opportunity of enhancing the knowledge to define science-based measures as well as narrowing the gaps between the Northen and Southern shores, calls for a joint (re)action. The paper reviews the state of the art of Mediterranean Sea science knowledge, sets of trends, capacity development needs, specific challenges, and recommendations for each Decade's societal outcome. In the conclusions, the proposal for a Mediterranean regional programme in the framework of the Ocean Decade is addressed. The core objective relies on integrating and improving the existing ocean-knowledge, Ocean Literacy, and ocean observing capacities building on international cooperation to reach the "Mediterranean Sea that we want".

Descriptors: Ocean Decade, Mediterranean Sea, Sustainable Development Goals, Marine science, Co-design.

\section{INTRODUCTION}

The Mediterranean Sea is a mid-latitude semi-enclosed marginal sea where many fundamental processes that characterize the general circulation of the world ocean also occur identically or analogously. The direct consequence is that the Mediterranean Sea can be considered as a "small-scale ocean" and a natural laboratory where field and numerical experiments as well as new strategies can be conducted in more favorable dimensional and environmental conditions. The basin, located at the border between two climate regimes, is disproportionately impacted by climate change: the Mediterranean currently warms at a rate of $20 \%$ faster than the rest of the globe (Lionello and Scarascia, 2018; Pisano et al., 2020, Cheng et al., 2021), thus experiencing dramatic changes that encompass the whole water column and menace the coastal zone at many levels of complexity (Cramer et al., 2018). Higher temperatures, as well as changes in precipitation patterns, runoffs, and storm regimes, coastal inundation and erosion, saltwater intrusion into freshwater aquifers, higher storm-surge flooding, loss of habitats, changes in nutrient concentrations, and displacement of lowlands/ wetlands are spreading the invasions of alien species. Furthermore, ocean acidification is endangering the life of many species, especially those producing hard shells and skeletons (Lemasson et al., 2017; HoeghGuldberg et al., 2017). The unique biodiversity of the basin is at stake.

Faced by three different continents, the Mediterranean is a vital source of nourishment and services that directly supports the livelihood of about 500 million people, especially in the poorest countries, and indirectly of the global population, essentially through maritime traffic and the attraction of tourism. Besides the environmental changes, the region is also undergoing intensive demographic, social, cultural, and economic changes. In this framework, the traditional knowledge, traditional technology, and customs contribute to guarantee the biodiversity, as recognized by the United Nations (Kang-Hyun Joo, 2019). Population growth combined with the growth 
of coastal urban hubs is generating multiple environmental pressures stemming from increased demand for water, food, and energy resources, air and water pollution caused by wastewater discharge or sewage overflows, waste generation, land consumption and degradation of habitats, unsustainable use of living resources, landscapes, and coastlines. These pressures are further amplified by tourism, often concentrated in the Mediterranean coastal areas, and by the climate breakdown. No single discipline can be sufficient to unfold this complexity nor decupling of scientific and humanistic culture can be further accepted to finally envision a sustainable, safe, depolluted and productive Mediterranean Sea - part of the Earth's Ocean and climate system thus fully implement Sustainable Development Goals (SDGs). The interconnectedness of science, culture, environment, economy, history and local knowledge is the key to tackle the challenges ahead and should be promoted by means of societal engagement. In this framework, from local and national to global level, Ocean Literacy enables bridging science with policy and society on relevant topics of ocean sustainability, observations and research (Eparkhina et al., 2021) and supports mutual nurturing of culture and science.

Multilateral international research on marine science in the Mediterranean has been promoted in the last century creating a well-established cooperation among scientific and research institutions. From this collaboration and further engaging key stakeholders at policy, private, and societal levels all along the services' chain, from upstream to intermediate to downstream, the Mediterranean regional observing and forecasting systems have been developed in order to provide systematic and long-term routine ocean data and products available for their rapid interpretation and dissemination. On the other end, an Action Plan for the Protection of the Marine Environment and the Sustainable Development of the Coastal Areas of the Mediterranean has been established under the United Nations Environment Programme (UNEP/ MAP), as a regional cooperation platform and a multiinstitutional framework for cooperation in addressing common challenges of marine environmental degradation. More recently, in the framework of the BlueMed Research \& Innovation Initiative (hereafter BlueMed Initiative), a shared vision to foster blue jobs and economy in the area was advanced, recognizing the value and role of science in supporting sustainable human activities at sea.

These multi-national well established collaboration framework will constitute the building blocks to reinforce the collaboration between science, policy makers, environmental agencies and economy actors and to proceed to further engagement of key stakeholders at policy, private, and societal levels.

Therefore, since the launch of the United Nations Decade of Ocean Science for Sustainable Development (2021-2030), a global framework to help generate ocean science solutions to key societal challenges and underpin the global Agenda 2030 (Ryabinin et al., 2019), the Mediterranean Sea has been recognized as a key component for the culture, development and economy of Europe, North African and Middle East countries and for the high potential of "transformative change" towards a sustainable future in a region.

In this view, two regional consultations, hosted by the Italian Oceanographic Commission (COI) and co-organised with the Intergovernmental Oceanographic Commission of UNESCO (IOC), UNEP/ MAP, Mediterranean Science Commission (CIESM), European Commission (EC) with the support of the BlueMed Initiative, have been conducted between January and November 2020, as part of the preparatory activities of the Decade.

"The Mediterranean Sea We Need for the Future We Want" workshop, held on 21-23 January 2020 at the IOC Office in Venice (Italy), brought together 159 experts from 32 countries as well as intergovernmental and international organizations and networks to discuss the Mediterranean Sea perspective in the light of the Decade's societal outcomes: a clean ocean, a healthy and resilient ocean, a predicted ocean, a safe ocean, a sustainably harvested and productive ocean, a transparent and accessible ocean, and an inspiring and engaging ocean (see www.oceandecade.org). The meeting facilitated regional and interdisciplinary discussions across sectors, providing the added-value of alignment and coordination of the scientific communities across all geographical regions surrounding the basin, and stakeholders across several key sectors of activities, bringing together the voices of the Mediterranean at the global level (Capasso et al., 2020). 
The virtual session "Co-designing the science and capacity we need for the Mediterranean Region", held on 11 November 2020 with the support of the Swedish Ministry of the Environment, gathered in remote in the middle of the pandemic 237 experts from 48 countries and more than 100 international organizations ranging from ocean and transdisciplinary research institutions, United Nations (UN) partners and Non-Governmental Organizations (NGOs) to the private sector, with the common objective to share lessons of relevant Mediterranean experiences in order to co-design the Decade actions. A synoptic view of the scientific and capacity development priorities resulting from regional consultations is available in Table 1. It has to be noted that while the attempt to reach different stakeholders to prepare the Decade activities proved successful, the variety of the engagement should be better balanced, e.g., in order to reflect the actual contribution of the private sector into relevant aspects of the blue economy. To close this gap, the role of National Decade Committees established at country level according to the principle of bringing all sectors of society as outlined in the Decade Implementation Plan (IOC, 2020) would be pivotal.

Driven by the UN Ocean Decade vision and Implementation Plan (IOC, 2020), the objective of this paper is to present the outcomes of these regional consultations as a new milestone towards an integrated, co-designed, and long-term strategic initiative to be developed in the Mediterranean, underpinning the Decade's implementation. Specific priorities are identified by declining them in the perspective of a sustainable Mediterranean Sea, whose peculiarity results both from physiographic conditions and historical and societal developments.

Table 1. Scientific and Capacity development priorities for the Mediterranean Region (IOC, 2021).

\begin{tabular}{|c|c|c|}
\hline \multirow{7}{*}{ : } & A clean ocean & $\begin{array}{l}\text { - Strengthen regional assessments and marine litter monitoring plans } \\
\text { - Upscale regional initiatives } \\
\text { - Acknowledge the Integrated Monitoring and Assessment Programme }\end{array}$ \\
\hline & A healthy and resilient ocean & $\begin{array}{l}\text { - Set up efficient adaptive/mitigating strategies to react to the accelerated paths } \\
\text { of change; carry out test case actions focusing on socio-ecological systems }\end{array}$ \\
\hline & A productive ocean & $\begin{array}{l}\text { - Implement test-case studies in the Mediterranean multi-cultural, socio- } \\
\text { economic diversified regional setting to develop innovative management } \\
\text { strategies based on 'socio-ecological system' } \\
\text { - Upgrade modelling exercises to improve spatial resolution, and integrate new } \\
\text { variables (benefiting of local knowledge, inter alia) to better deal with complex } \\
\text { system }\end{array}$ \\
\hline & A predicted ocean & $\begin{array}{l}\text { - Enhance observing and predicting capabilities } \\
\text { - Set up efficient adaptive/mitigating strategies to react to the accelerated paths } \\
\text { of change; carry out test case actions focusing on socio-ecological systems } \\
\text { - Build a laboratory for climate change }\end{array}$ \\
\hline & A safe ocean & $\begin{array}{l}\text { - Develop impact-based forecasting of marine multi-hazard early warning } \\
\text { systems } \\
\text { - Improve coastal and deep-sea observational systems }\end{array}$ \\
\hline & $\begin{array}{l}\text { A transparent and accessible } \\
\text { ocean }\end{array}$ & $\begin{array}{l}\text { - Strengthen the science-policy interface and the flow of knowledge from } \\
\text { scientists to the diverse regional policy frameworks } \\
\text { - Pursue an open-data approach to ocean data and knowledge } \\
\text { - Understand future links with economy and societal needs }\end{array}$ \\
\hline & An inspiring and engaging ocean & $\begin{array}{l}\text { - Enhance 'Mediterranean Sea literacy' and participatory research } \\
\text { - Improve connection and collaboration with existing Mediterranean networks } \\
\text { and organizations }\end{array}$ \\
\hline & acity development priorities & $\begin{array}{l}\text { - Establish North-South and East-West collaboration aligning regional policy } \\
\text { frameworks and initiatives } \\
\text { - Build structured partnerships to overcome political constraints } \\
\text { - Draw up a shared educational strategy for sustainable development }\end{array}$ \\
\hline
\end{tabular}


The Mediterranean Sea is unique in its biodiversity, with $28 \%$ of endemic species, and tight interconnection between marine ecosystems and human activities. About 150 million people are living in the coastal areas, and the basin provides the pathway for $30 \%$ of the global sea-borne trade volume (EC, 2015; BlueMed, 2018). Increasing coastal urbanization, human pressures, exerted from marine/maritime activities and climate change are strongly affecting the status of the region. Recent assessments (UNEP/ MAP, 2017; UNEP/MAP and Plan Bleu, 2020) showed Mediterranean ecosystems and living resources to be far from Good Environmental Status (GES, COM(2014) 97), as a result of the combinations of the abovementioned factors.

The last decade has seen the increase of pollution, threatening marine environment, life and health at any level and exacerbating the status of several populations (Casabianca et al., 2020). This became rapidly a critical problem: dead zones, anoxic areas and hot spots of chemical pollution affect ecosystems along with the marine litter (i.e. micro-and nano-plastics and associated Persistent Organic Pollutants (POPs) and Endocrine Disrupting Chemicals (EDCs)) that affects marine environment and organisms mainly through entanglement and ingestion, and colonization and rafting of invasive species or species at risk. Drastically reducing pollution and remediating polluted areas is one of the main transboundary challenges to ensure a "clean Mediterranean Sea", increasingly recognizing the existing cumulative threats, including historical, and the need to address them in a coordinated manner, in order to maintain this worldwide heritage as well as livelihoods. The damage and associated social costs of pollution also extend to the economic sectors, such as tourism, aquaculture and fishery, and shipping, and have multiple direct and indirect impacts on human health (review in Landrigan et al., 2020). The nature and magnitude of these effects are only beginning to be understood.

As one of the major stressors affecting the Mediterranean, the fate of pollution needs to be considered in the framework of multiple impacts scenarios driven by climate change and effects of human activities on the marine environment, also in relation with marine hazards. Multiple stressors are also threatening marine biodiversity, with fisheries among the main drivers of species extinction (e.g., Dulvy et al., 2014). Overfishing has also characterized this Sea and great effort is required to counter this serious problem (FAO, 2020). The on-going transitions in the community composition are modifying marine food webs affecting the most sensitive organisms, playing major roles in the ecosystem functioning and hampering resilience. $A$ "healthy and resilient Mediterranean Sea" can be obtained only if marine ecosystems are mapped, monitored, and protected, and the multiple impacts, including climate change, are measured and reduced, in a way that the provision of ecosystem services are maintained. We are now at a crossroads where the relationship between the ocean and world population urgently needs to move towards mutual aid. As it will be explored in the following, citizen-science initiatives and Ocean Literacy have a key role to play in building and sustaining such relationships.

Enhancing the ocean observing capacity, measuring the Essential Ocean Variables (EOVs, www. goosocean.org/index.php?option=com_content\& view $=$ article\&id $=14 \&$ Itemid $=114$ ) and understanding the complexity of the system to develop sound models and address evidence-based solutions is the key to build a wealthy and safe Mediterranean area. The renowned expertise of Mediterranean scientific community in operational oceanography and forecasting (Tintorè et al., 2019; Le Traon et al., 2019) represents a remarkable strength to build on for future development of the in situ and satellite observing systems and modelling exercises to improve spatial and temporal resolution, and integrate new variables (benefiting of local knowledge, inter alia, and technological developments) and scale-up so as to better deal with complex systems. The knowledge of the sea floor morphology is nowadays also increasingly achievable both in shallow and deep-water environments. In fact, in the last decade seafloor mapping technique have dramatically improved, allowing centimetric resolution and therefore quantitative definition also of the impact of erosional events and definition of the impact of human activities (Madricardo et al., 2019; Fassoni-Andrade et al., 2021). Such knowledge is the basis also for attempting a broadening of the citizen-science approach by bringing to the public observations that are beyond the normal, direct, and inevitably anthropocentric, view of the environment. 
However, it is worth noting that the Mediterranean Sea is still neither adequately observed nor fully understood in terms of early warning observations and forecasting of the impacts of climate change and anthropogenic stressors, from the deep and open sea frontiers to the coastal areas (Melaku Canu et al. 2010; Zunino et al. 2021). Hence, the capacity is limited to understand current and future Mediterranean conditions, project their change and impact on human wellbeing and livelihoods. To tackle the formidable challenge presented by the need to observe, assess and predict coastal seas and nearshore marine ecosystems, first of all existing data gaps and lack of infrastructures in some parts of the basin need to be reduced and measurements of the biological essential variables extended. The superposition of a variety of coexisting inputs and pressures on coastal and nearshore areas can alter the ecosystems. Moreover, the interplay of many physical, chemical and biological processes acting on a wide range of spatial and temporal scales add extra complexity to an already complex picture. Factors such as river inputs, spatial anisotropy induced by the coast, benthic-pelagic coupling, inputs related to terrestrial-based economic activities are essential components in coastal areas. These are also characterised by very dynamic processes yielding a high variability in space and time, directly influenced by diurnal and seasonal changes, and with additional factors to be accounted for when compared to the open ocean. Coastal marine areas are the focus of the interaction with the land, on one side, and the forcing by the broader shelf water body on the open-sea, and are the most prolific with activities by users extracting services that are crucial for several marine economic undertakings. Improving our ability to predict ecosystem responses to anthropogenic forcing and to move toward a "predicted Mediterranean Sea" is a key priority in identifying pathways, policies and actions for monitoring, regulation, surveillance, defence, hazard assessment and alert, and many other needs that often require regular and timely support from coastal observation and forecasting systems.

The key marine hazards requiring a focus to achieve a "safe Mediterranean Sea" are, among others: storm surges, tsunamis, harmful algal blooms (HABs), and coastal erosion (Figure 1). Storm surges represent a recurring risk for the population living along

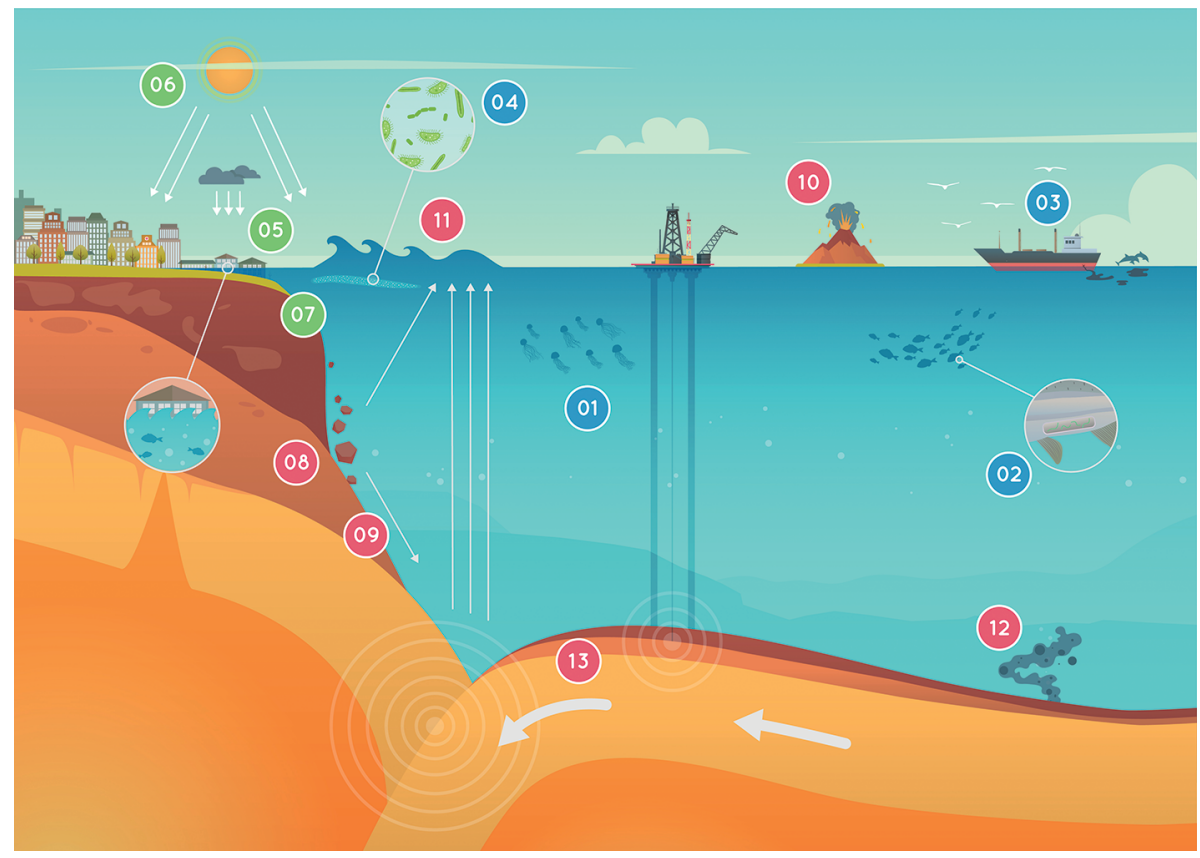

Figure 1. Infographic illustrating the main Biological Hazards (01-Jellyfish proliferation; 02-Impact of parasites; 03-Impact of oil spills; 04-Harmful algal blooms), Extreme Climate Events (05-Storms and surges; 06-Heat waves; 07-Coastal erosion) and Geological Hazards (08-Landslides and slope Instability; 09-Submarine erosion; 10-Volcanism; 11-Tsunami; 12-Destabilization of gas; 13-Induced and natural earthquakes) investigated at CSIC, Spain. (Design Investid Plus. From: Sallarés et al. (in press) From a safer Ocean: towards marine hazard impact mitigation. Libro Blanco (SIC). 
the coasts all over the world (Androulidakis et al, 2015). Major tsunamis are relatively low-probability occurrence phenomena which may have very highconsequences and can be triggered by seismic, volcanic, landslides and meteorological sources. In the Mediterranean region, the risk associated with both storm surges and tsunamis is enhanced because its population is concentrated near the coasts. A risk source is also represented by HABs hampering aquaculture activities, seafood safety, marine life and key economic activities for the area such as recreation and tourism, a sector that represents, with few hundreds of millions of tourists every year (except for the pandemic year), more than $90 \%$ of the annual economic value of the area, counting connected activities (Randone et al., 2017).

The relevance of a better understanding of risk drivers, risk assessment and reduction in a multi-hazard framework is even more urgent in the incumbent threat of climate change. According to increasing evidence (e.g., https://ocean.si.edu/through-time/ ancient-seas/sea-level-rise), the projected sea level rise in the Mediterranean Sea may exceed $1 \mathrm{~m}$ by year of 2100 , thus potentially increasing the risk related to erosion, flooding and salinification of low-lying coasts in the absence of major additional adaptation efforts. In fact, coastal flooding, erosion and tsunamis, enhanced by sea-level rise, pose at risk several UNESCO World Heritage Sites (WHS) characterizing the Mediterranean region. By 2100 , flood risk may increase by $50 \%$ and erosion risk by $13 \%$ across the region, with considerably higher increases at individual WHS (Reimann et al., 2018).

Marine hazards in the Mediterranean region lead to an ever-increasing risk because more and more assets and people are getting exposed (Figure 2).

A conservative value of the Mediterranean Sea economic assets is in the order of US\$ 5.6 trillion, generating an annual economic value of US\$ 450 billion (Randone et al., 2017). Nowadays, society depends on the ocean more than at any time before.

Ensuring a "sustainable (harvested and) productive Mediterranean Sea" depends on the development of a sustainable management of ocean and coastal resources and on the integration of marine spatial planning with coastal management as key tools to support informed decision making. Despite the recognition of the potential of established, emerging and innovative sectors of the blue economy to bring opportunities for investment for the future development of coastal communities (EC, 2020), effective exploitation of available tools, including information

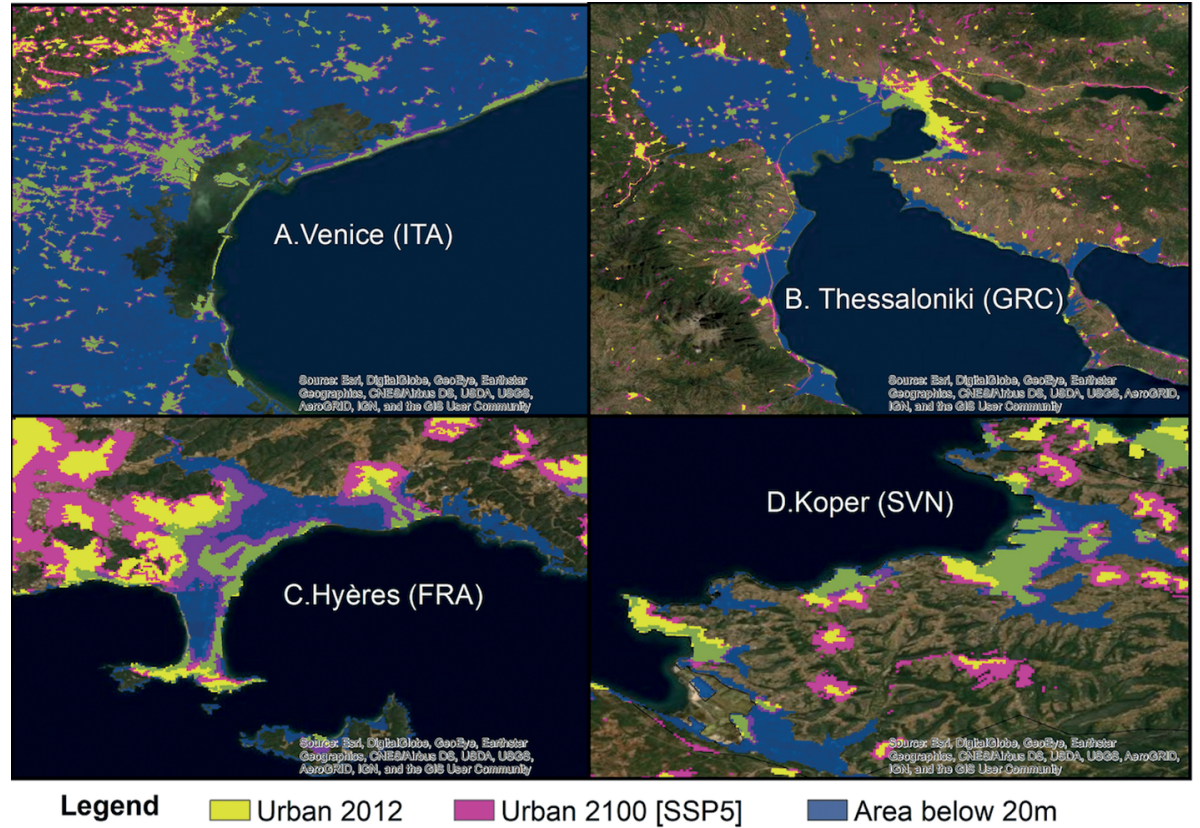

Figure 2. Examples of potential urban development in four selected coastal regions as modelled by Wolff et al. (2020). In dark blue, the area that lies below $20 \mathrm{~m}$ is indicated. 
and communications technology (ICT), to support decision makers and stakeholders in decoding the complexity of the system and integration of ocean science with social and economic science is still lacking. Science-based safe and sustainable thresholds for economic operations in the Mediterranean Sea need to be defined in order to drive the sustainable exploitation of non-renewable resources and the resources based on the Mediterranean Sea natural and cultural heritage while preserving the environment. Sustainable food production, tackling biodiversity and resources, need to be implemented and the links and mutual feedback between tourism and the environment in the perspective of the circular and inclusive blue economy reinforced.

In this context, integrating data represents an unavoidable tool for assessing the status of marine systems and societies in all of the most urgent issues like biodiversity loss, pollution, healthy seafood products and its fundamental interaction with climate change phenomena (Tunesi et al., 2013; Canonico et al., 2019; Sloyan et al., 2019) as well as with key social and economic activities. To be fit-for-purpose and in the view of a "transparent \& accessible Mediterranean Sea", data needs to be processed in a workflow made of many steps: collection, validation, aggregation, elaboration, and so on. Such steps are usually carried out by different bodies and/or authorities using different spatial and temporal scales, but they constitute, as a whole, the foundation to build up the marine data value chain which will serve the data services and users. Long-term archiving is also crucial as monitoring data are used to assess trends, validate and calibrate models, and even when they are considered inaccurate, they represent a benchmark for the definition of accuracy.

Furthermore, ensuring the complete openness of scientific knowledge will allow understanding the future links with economy and societal needs, the formulation of environmental policy and management plans, unlocking ideas and innovation, through a participatory process that is timely and encompasses diversity of interdisciplinary research and interaction with non-academic representatives. According to Shepherd (2018) "to provide a more integrated approach to marine data, allowing the user to search for, visualize, and retrieve in a common way all measurements with one single command wherever the data are stored, the EU embarked upon the construction of a European Marine Observation and Data Network
(EMODnet). To maximise innovation and minimise bureaucracy, marine data should be free of charge and free of restrictions on use".

Continuous engagement across the diversity of stakeholders, societal actors, and economic sectors is the key to pursue sustainable management of the human activities in the ocean. While Ocean Literacy has been recognized as a key enabler of virtuous engagement, and relevant initiatives have been built targeting the Mediterranean, a consistent effort should be devoted to connecting experiences, exchanging practices, and supporting collaboration among the actors working on science communication and outreach, harmonized among the riparian countries. In this way, reaching an "inspiring and engaging Mediterranean Sea" will become possible. As enabler, Ocean Literacy is required not only for bringing science to society and its many actors and sectors but also for inspiring science in delivering fit-for-purpose solutions for sustainable development, bridging the gaps between the ocean science stakeholders, users, and funders in various economic and cultural sectors. It is thus an imperative in establishing science-policy and public-private interfaces (Mackenzie et al., 2019), helping the actors to share the common understanding of basic concepts and facts about the ocean, by developing common narratives as well as common values and personal and emotional connections with the ocean (EU, 2020). Ocean Literacy is also an important contributor to integrating traditional knowledge in the knowledge-generation and sharing process.

In the Mediterranean, it can particularly help narrowing the North-South gap, including in education and science and technology capacities, by favouring knowledge exchange and co-design.

Taking the state of the art into consideration, this White Paper includes the set of trends (section 2), capacity development needs, specific challenges (section 3), and recommendations (section 4) for each Decade's societal outcome, including cross-cutting issues. The synthesis of these findings as well as of the consultation process is finally reflected in the proposal of a Mediterranean Sea community contribution to the Decade (section 5).

\section{CURRENT STATUS AND TRENDS}

This section presents a snapshot of the key issues faced by Mediterranean Sea for each Decade's 
outcome. Preliminary and macro insights on actions to be undertaken can be also derived, projecting into the gaps and challenges.

\section{A clean Mediterranean Sea}

As we saw in the previous section, the Mediterranean basin is threatened by multiple stressors associated with the rapid expansion of coastal populations, urbanization, changes in agricultural, industrial and shipping patterns, overfishing and exploration and extraction of offshore minerals and hydrocarbons (Danovaro et al., 2020; Sprovieri et al., 2020; Sprovieri et al., 2021; Melaku Canu et al., 2015). In addition, $30 \%$ of the world maritime traffic is passing by the basin, being the first tourist destination of the world. Also, the basin buffers inland pollution, including significant riverine inputs because of large rivers (Po, Nile, etc.).

Different aspects can be considered as the main causes of marine pollution. The UNEP/MAP Quality Status Report (UNEP/MAP, 2017) highlighted the chemical contamination of sediments and biota, eutrophication and marine litter as the major issues requiring coordinated policy and urgent management responses in order to stem the tide of degradation of the Mediterranean ecosystems. These pollutants enter the Mediterranean Sea as land-based sources either via discharge points and dumping grounds (point source pollution) or from surface fluvial runoff (nonpoint source pollution). Pollutants also enter the marine and coastal environment through atmospheric deposition or due to marine activities such as shipping, mining, and oil and gas exploration. Although land-based sources are dominant in generating marine litter, sea-based sources actively contribute to the problem for some parts of the basin, reaching even $80 \%$ in Malta (Liubartseva et al., 2019).

The main types of chronic pollutants in the Mediterranean are oxygen-depleting substances, heavy metals, POPs, hydrocarbons, nutrients introduced by human activities and plastic (Figure 3). While a decrease of general chemical contamination and oil spills accidents have been described, there are still some point sources of priority, emergent contaminants and new contamination schemes (ship emissions, acidification, tourism, etc.).

Offshore waters of the Mediterranean Sea are characterized as oligotrophic, but the highly populated coastal zone and the riverine input induce eutrophic trends in coastal areas (Sammartino et al., 2015). The main coastal areas in the Mediterranean which are historically known to be affected by eutrophication are the Gulf of Lion, the Gulf of Gabès, the Adriatic Sea, the North Aegean Sea and the SouthEast Mediterranean (Colella et al, 2016). The assessment most often show that these areas do not reach GES (UNEP/MAP, 2017). Using satellite and model data from the European Commission's Copernicus Marine Environment and Monitoring Service (CMEMS, www. marine.copernicus.eu), UNEP MAP (2017) reported an overall increasing trend of chlorophyll concentration in the Mediterranean Sea over the past twenty years, and a clear increase in the western part of the basin. Criteria for reference conditions for key nutrients in the water column should be harmonized throughout the region.

As regards chemical pollution, the main activities contributing to the emissions are wastewater treatment plants, metal production, pulp and paper production, the chemical industry, and other activities (dying of textiles, tanning, ship building, painting or paint removal). Interestingly, the trends and levels of pollutants have generally decreased significantly in the most impacted areas in the Mediterranean Sea after the implementation of environmental measures (UNEP/MAP and Plan Bleu, 2020).

However, several point and diffuse pollution sources are still releasing both priority and emerging chemical contaminants into the Mediterranean. Measures and actions should thus focus on hotspots associated with urban and industrial areas along the coasts (UNEP/MAP, 2017). Regrettably, the intervention scenario is complicated by the lack of data. Limited data availability with insufficient geographical coverage and quality assurance to allow for proper regional assessment, and mostly non-detected concentrations, is shown on petroleum hydrocarbons and POPs from the national coastal monitoring networks.

While levels of heavy metals (cadmium, mercury, lead) in coastal waters, assessed from bivalves and fish against Environmental Assessment Criteria, show a more-or-less acceptable environmental status, concerns regard the coastal sediment compartment for lead and total mercury, indicating an impact from these chemicals, including in foodstuff for lead. 

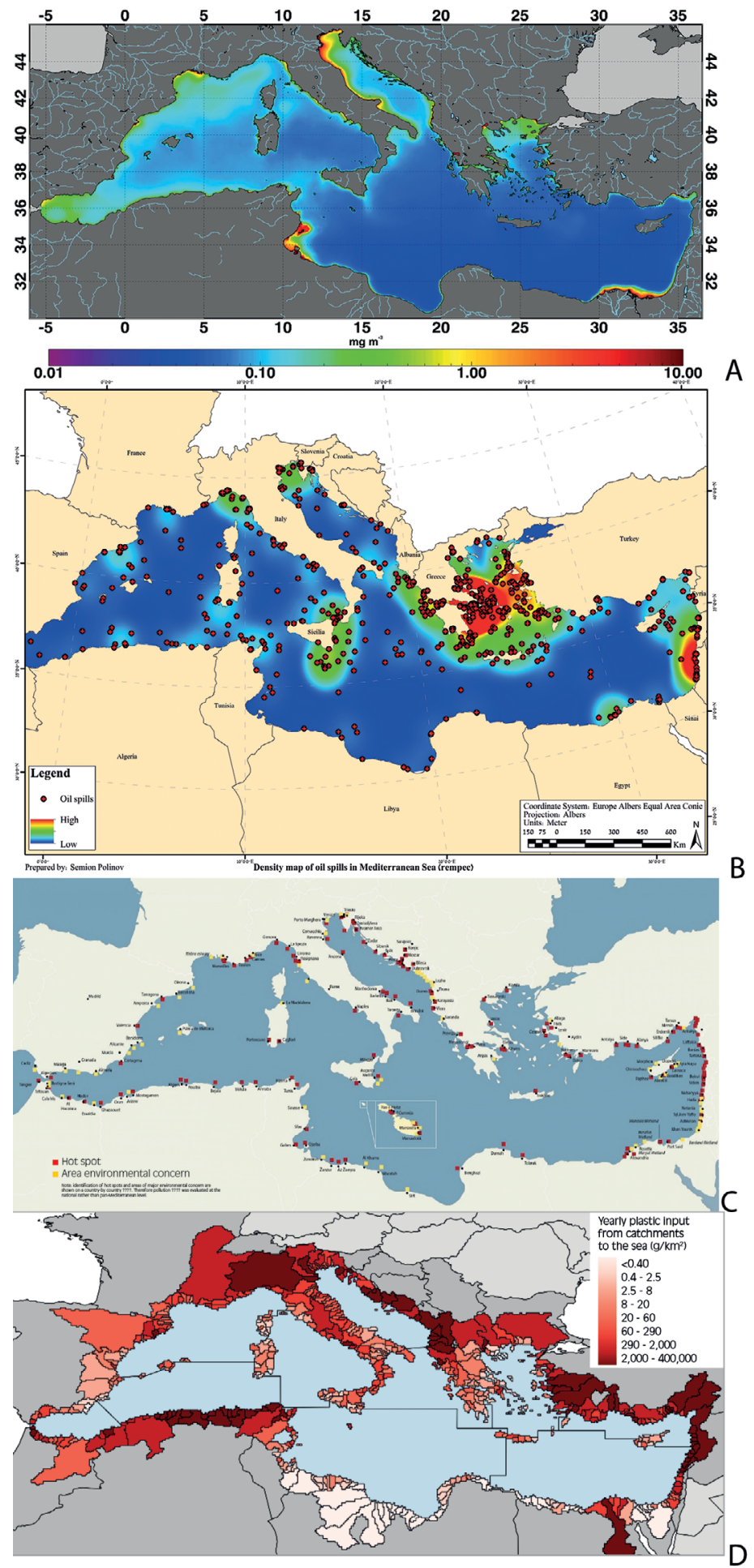

Figure 3. An overview of the main pollution issues in the Mediterranean Sea. A: Chlorophyll (eutrophication, Colella et al, 2016); B: Oil spills (1977-2017, Rempec databases); C: Major hot spots of pollutions (UNEP/MAP and Plan Bleu, 2020); D: Modelled inputs of plastic pollution (UNEP/MAP and Plan Bleu, 2020). 
Emerging pollutants refers to a heterogeneous set of thousands of molecules whose presence in the environment has been detected only recently. This category includes personal care products (antiseptics, sun lotions, cosmetics, etc.), flame retardants, additives, plasticizers such as phthalates, nanoparticles used in food, medicine, construction and textiles, plant-derived substances, perfluorocarbons, pharmaceuticals antibiotics, and non-halogenated substances. These substances can be toxic for marine organisms and humans, if not removed from waste waters. The study of their interactions with the environment and human health and their treatment is extremely complex and is largely insufficient for a number of substances. Although wastewater treatment is improving to eliminate certain substances, we are far, in the Mediterranean Sea, from phasing existing substances out, also due to lack of regulation on the emergence of new substances.

The Mediterranean Sea, representing $1 \%$ of the global oceanic waters, is also one of the world areas most highly affected by marine litter due to an increase in plastic use, the lack of recycling, unsustainable consumption patterns, inadequate waste management, high pressures from tourism and shipping, coupled with significant riverine inputs. Inputs of plastics into the sea, as estimated in 2015, are at the level of over hundreds of tons per day (UNEP/ MAP, 2015), depending on the coastal population, which may vary from country to country, representing more than $2 \%$ of the total inputs in the world's oceans. Plastics account for up to 95 to $100 \%$ of total floating marine litter and more than $50 \%$ of seabed marine litter. The Mediterranean is especially affected by microplastics, with concentrations at the sea surface largely above 100,000 items per $\mathrm{km}^{2}$ and maxima above 64 million floating particles per $\mathrm{km}^{2}$. These concentrations are projected to further increase in years to come.

In the majority of Mediterranean countries, the root causes of pollution are found in ineffective/ inefficient waste and wastewater management, in limited regulations, unsustainable consumption patterns, in the increase of plastic use, and possible illegal practices (Figure 4).

In some areas, up to $58 \%$ of the municipal solid waste collected is still disposed in open dump sites (UNEP/MAP and Plan Bleu, 2020), and less than one third is recycled, while plastics recycling is less than 6\% (WWF, 2019).

Land-use nutrient input is expected to increase, although the many regional and national efforts to mitigate their impact on the ocean and ecosystem. A decrease of plastic wastes remains a challenge and point sources of chemical pollution still exist.

Transitioning to a sustainable and clean economy will require urgent and profound changes in both production and consumption patterns, being the

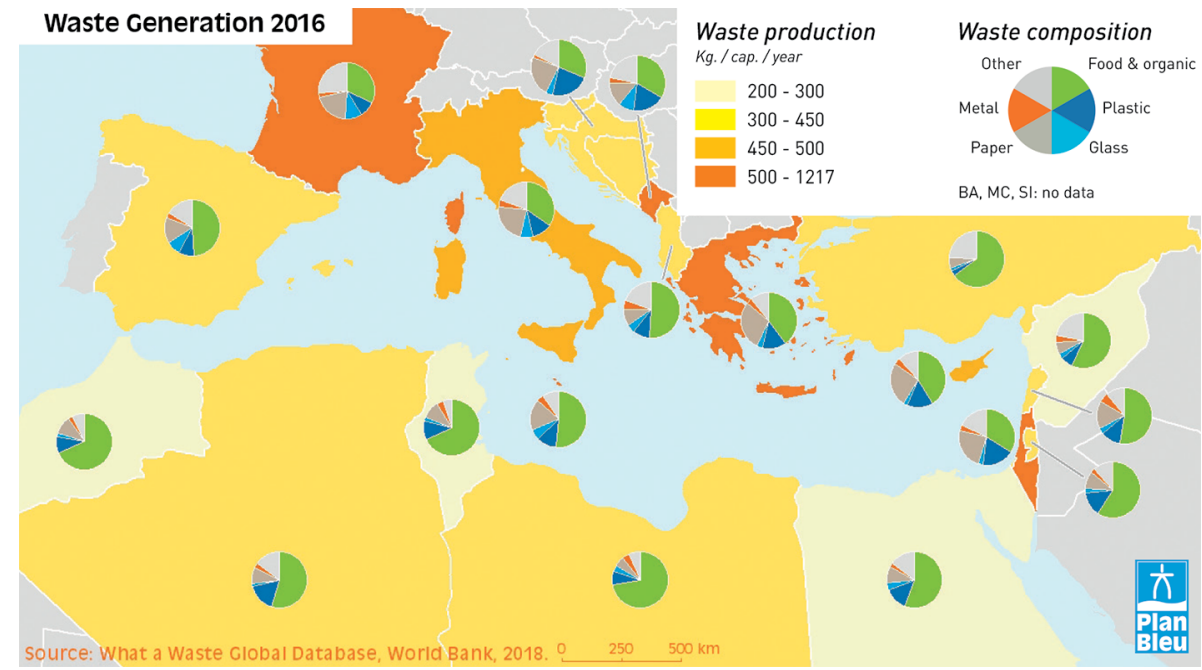

Figure 4. Waste generation and composition in Mediterranean countries, 2016 (Source: What A Waste Global Database, http://datatopics.worldbank.org/what-a-waste/). 
Single-use plastics product EU Directive (2019) entered into force in July 2021 a strong signal in this regard.

\section{A healthy and resilient Mediterranean Sea}

The multitude of stressors affecting the ocean caused a great acceleration of marine ecosystem degradation during the last five decades. This applies also to the Mediterranean Sea, a highly variable ecosystem in terms of hydrological and biodiversity changes. To maintain the provision of goods and services, marine ecosystems need to be mapped, monitored, and protected, and the multiple impacts, including climate change, measured and reduced.

For the European Member States of the Mediterranean Sea, the Marine Strategy Framework Directive (MSFD) - i.e., the first European Union (EU) legislative instrument to protect marine biodiversity as the cornerstone for achieving GES - drives the ecosystem assessment. At pan-Mediterranean level, in 2008, the Contracting Parties to the Barcelona Convention decided through their COP 15 Decision IG.17/6 (UNEP(DEPI)/MED, 2008) to progressively apply the Ecosystem Approach (EcAp) to the management of human activities that may affect the Mediterranean marine and coastal environment for the promotion of sustainable development. Both EcAp and MSFD define indicators suitable to capture the status of marine ecosystems based on information originated from monitoring efforts, as to inform policy about this status, drive marine protection in support of marine-related economic and social activities.

The European Commission's 2012 Green Paper (EC, 2012) set out a vision for easily accessible, interoperable and free of restrictions on use digital seabed map of European waters covering topography, geology, habitats and ecosystems, accompanied by timely observations and information on the present and past physical, chemical, and biological state of the overlying water column, and associated data on human activities. As part of its Marine Knowledge 2020 strategy, the European Commission's DirectorateGeneral for Maritime Affairs and Fisheries (DG MARE) launched the European Marine Observation and Data Network (EMODnet, https://emodnet.eu/en) initiative undertaken by partnership of over a hundred and fifty organizations working together to assemble marine data from diverse sources and resources and build gateways to national, regional or thematic repositories, essential contribution to the data and information sharing provisions in the MSFD and the Maritime Spatial Planning (MSP) Directive (Martín Míguez et al., 2019). For example, the EMODnet Chemistry portal for marine data is currently compiling at the European scale monitoring and research data on beach litter abundance, project data on benthic litter and microliter floating data (www.emodnet-chemistry.eu/marinelitter) extensively used to set assessment values for the MSFD Descriptor 10 on 'Marine Litter' (Molina Jack et al., 2019). EMODnet helps ensure the integrity of in-situ data used by the Copernicus program. Data from both EMODnet and Copernicus are distributed according to INSPIRE protocols (https://inspire.ec.europa.eu/metadata-codelist/ProtocolValue/) and are thus interoperable.

As far as concerns protection strategies, Marine Protected Areas (MPAs) set on coastal, shallow (24.68\%: 0-15 m depth) sites, organized in networks of connected MPAs (Boero et al., 2016) are considered to be playing in the future a central role in the recovery of declining species, habitats and ecosystems (Davidson and Dulvy, 2017). They could support inclusive economics, such as small-scale fisheries (SSF) and ecotourism (Ban et al., 2019), as well as play as "sentinel" sites to observe and counteract climate change, especially in blue carbon ecosystems (e.g., Posidonia meadows, Kaal et al., 2019). Nevertheless, a mere $8.9 \%$ of the Mediterranean surface is presently under a protection status (UNEP/ MAP and Plan Bleu 2020).

Ecosystem modelling has proven to be a suitable instrument to integrate information from monitoring, assess and drive protection strategies (Solidoro et al., 2009). A robust scientific and technological capacity is available to pursue a more advanced monitoring of the Mediterranean Sea: e.g., CMEMS, coastal modelling, and pollution modelling. This 'already-built' capacity can tackle multiple challenges and contribute to solutions, such as supporting a better assessment of climate change effects. In this context, the Copernicus Marine Service is an observation platform that tightly interconnects the same international scientific networks that support and exploit it (e.g., Mediterranean Operational Network for the Global Ocean Observing System - MONGOOS, European Global Ocean Observing System - EuroGOOS, Expert 
Team on Marine Environmental Emergency Response - ETMEER).

To obtain a healthy and resilient Mediterranean, it is necessary to promote integration between ecosystem conservation (protection), generation of knowledge of the physical, biogeochemical and biodiversity dynamics on appropriate time scales (monitoring), understanding the effect of long-term cumulative stressors to define the basin vulnerability (assessment), and displaying suitable predictive tools (modelling). Increasing our knowledge about organismal plasticity and response capability, in particular for ecosystem engineer species, is also mandatory, as well as promoting ecosystem restoration. Crucial to the aim is the recognition of long-term impact of humans, starting well before the industrial revolution with repeated episodes of forest clearance and radical change in land use (since the Roman Empire) accompanied by modifications including of the hydrological network through river diversions leading to radically modified coastal and deltaic areas (Maselli and Trincardi, 2013) with substantial impact on coastal ecosystems.

\section{A predicted mediterranean Sea}

Better prediction of responses, feedback and warning to cumulative human impact and multiple stressors and hazards, and a better understanding of the Mediterranean ecosystem functioning and health, is the basis for its management and adaptation.

In the last 30 years, the scientific community working in the Mediterranean region has cooperated within a thorough EU strategic planning contributing to the development of regional observing and forecasting systems, which up-to-date evolved to the most advanced research infrastructures and instruments at global and European scale, including CMEMS, thematic clusters of EMODnet, SeaDatNet (www.seadatanet.org/), Joint European Research Infrastructure of Coastal Observatories (JERICO Rl, www.jerico-ri.eu/), International Center for Advanced Studies on River - Delta - Sea Systems (DANUBIUSRl, www.danubius-ri.eu/), European Plate Observing System (EPOS-ERIC, www.epos-eu.org/epos-eric), European Multidisciplinary Seafloor and watercolumn Observatory (EMSO-ERIC, www.emso-eu. org), European Contribution to the Argo programme (Euro-Argo ERIC, www.euro-argo.eu), Integrated Carbon Observation System (ICOS Rl, www.icos-cp. eu/) and Long-Term Ecosystem Research Network (LTER, www.lter-europe.net/lter-europe).

The MONGOOS data center (www.mongoos.eu/) data-center offers a catalog of data from monitoring platforms deployed in the basin. It constitutes a comprehensive catalog of oceanographic measurements available in the region from coastal and open ocean in-situ platforms, High Frequency (HF) radars, profilers and drifters, and gliders, with 47 members from 14 Mediterranean countries providing information of the sea state in near real-time and an updated state of the art of monitoring systems since 2012. Operational modelling systems (Figure 5) developed by MONGOOS members are described in Capet et al. 2020. Access to real-time data from
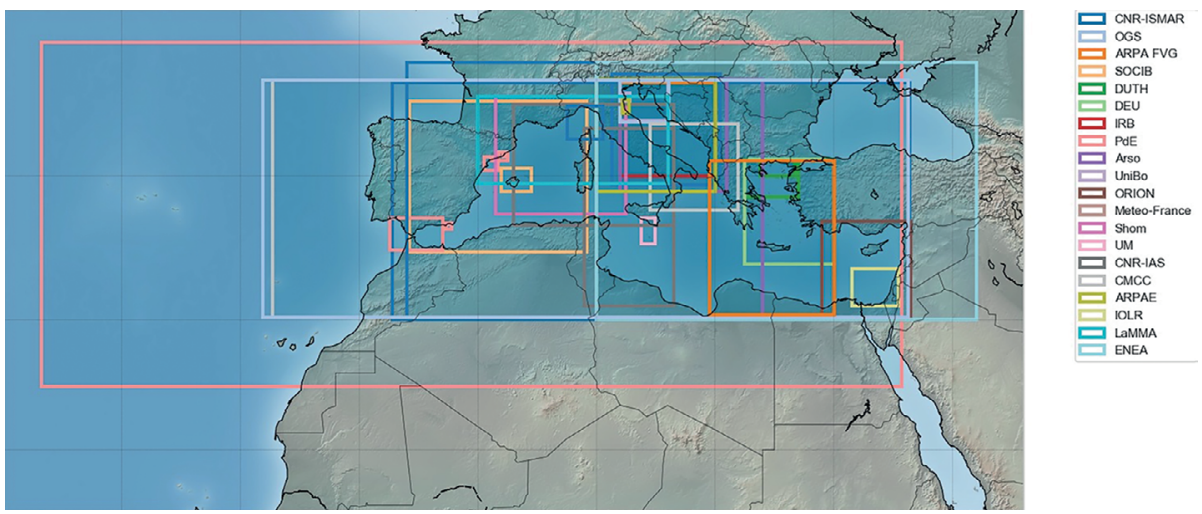

Figure 5. Map of the operational modeling domain of the Mediterranean Sea (Capet et al., 2020). 
most MONGOOS monitoring platforms is provided through the CMEMS In Situ Thematic Centre (TAC) and the EMODnet Physics Portal (Tintorè et al., 2019). Deep Sea Observatories equipped with multiple sensors, placed along the water column and on the seafloor are present in the Mediterranean Sea. They constantly measure different biogeochemical and physical parameters that address natural hazards, climate change and marine ecosystems and are part of the EMSO ERIC. A big effort was also made to collect and make accessible historical in situ measurements acquired by the science community during ship cruises carried out in the Mediterranean in the last century. These data, hosted by SeaDataNet and/or EMODnet thematic portals for bathymetry, geology, seabed habitats, chemistry, biology, physics, and human activities are particularly relevant for the fulfillment of the Sustainable Development Goals (SDGs). Despite these efforts, gaps in observation on CentralEastern Mediterranean and on the Northern African coasts still exist.

Since the early 90 's, space-based observations played a crucial role in the development of the Mediterranean Sea observing system (Minnett et al., 2019) highlighting the importance of the development of regional satellite products in order to retrieve more accurate biogeochemical products (Volpe et al. 2012; Organelli et al., 2016; Organelli et al., 2017). Mediterranean regional satellite products are regularly updated and made available by CMEMS Satellite TACs. The new frontiers will be to increase the spatial and temporal resolution of the satellite products, improve their quality especially in coastal areas and to enlarge the number of biogeochemical variables monitored from space.

In the last three decades, several observation-forecasting integrated systems have been established in the Mediterranean Sea to support the implementation of environmental quality targets and objectives, such as the CMEMS and several other local (national) systems. They provide periodic updates on the state of the Mediterranean basin (Tintoré et al., 2019; Le Traon et al., 2019), as well as outlooks, forecasts, projections, and product delivery (von Shuckman et al., 2020) of the main EOVs. The whole chain of integration, sharing and downstreaming of the information at the basin scale and at the local level, has been improved in the last years, also thanks to a number of
Copernicus service evolution projects. However, assimilated models and products are limited to physics and to a few main biogeochemical variables (Salon et al., 2018). According to Capet et al. (2020), 70\% of the operational and preoperational products developed in the Mediterranean Sea targets the processes driven by the physical oceanography, such as marine safety, oil spill, sea level monitoring, storm surge, and only $10 \%$ of them address water quality, $6 \%$, hypoxya, and the minority of them devotes to other services focusing on the biological components, such as invasive species and living marine resources. Moreover, the specificities of coastal seas are poorly represented.

Improved understanding of the present and future conditions in the Mediterranean Sea is a prerequisite to the development of sustainable ocean economic policies and ecosystem-based management. Such information is needed within or beyond national jurisdictions, servicing and connecting nations and citizens.

While a substantial work has already been undertaken in past decades in this direction, including:

- understanding of the basin-scale, mesoscale, and sub-mesoscales circulation and water masses generation and propagation at different time-scales: from Seasonal-to-Decadal Climate Forecasting;

- analysis and research on ecosystem state and ecosystem functioning;

- using the opportunity offered by European research infrastructure and major programs, such as CMEMS, SeaDataNet, EMODnet, to setting up a Mediterranean integrated and observing and modelling system based on distributed centers that gradually has been transitioned to operation and now is fully operational and therefore can support the development of blue economy products;

- setting up networks of observational platforms and national forecasting systems linked with the regional system;

- develop together with intermediate users prototype tools and/or downstream systems to demonstrate how the system can respond to user's needs down to societal benefit, as for example the observation and modelling tools developed to mitigate the risks and impacts associated with oil spill designed with the Regional Marine Pollution Emergency Response Centre for the Mediterranean Sea (REMPEC).

There is still much to do to support sustainable management trends through observations. For 
instance, to assess the impact of blue economy developments on the marine environment, the adequacy of the monitoring capacity needs to be constantly assessed, and adapted taking into account users' needs, coping with fast changing monitoring protocols, tools and associated parameters, evolving under the combined effect of new technological developments (AUV, drones, sensors...) and rising societal needs. A first example of this type of assessment was carried out in the framework of the MedSea Checkpoint project (https://emodnet.eu/en/checkpoint/medsea, Pinardi et al., 2017) demonstrating the importance of a continuous evaluation of the system and products capability to respond to policy and economy user's needs.

\section{A safe Mediterranean Sea}

Storm surges in the Mediterranean region are a relatively common phenomenon, impacting natural environments, damaging infrastructures and affecting economical assets. Coastal floodings develop seasonally, reflecting a combination of astronomical (tides) and meteorological (storm surges) forcing whose impacts can be exacerbated in areas of natural or anthropogenic subsidence (Trincardi et al., 2016). The vulnerability to flooding is therefore in large part the consequence of human uses of the coastal region, including historical diversion of rivers, modification of coastal morphology (including excavation of artificial inlets) and pumping of fluids (freshwater and, in some areas, hydrocarbons) from beneath the coastal areas resulting in high rates of coastal subsidence (Herrera-García et al., 2021). Climate projections and analyses of tide gauge data show different trends in frequency, magnitude and duration of the extreme sea level events in the region, often associated to the rise in the relative mean sea level (Androulidakis et al., 2015; Galassi and Spada, 2014; Lionello et al., 2012; Marcos et al., 2015). The available observational records are too short for assessing multidecadal trends, with the exception of the Northern Adriatic Sea, where an increase in the number of storms is reported (Pomaro et al., 2017). The projected trends have a direct impact to expose the Mediterranean societies to more frequent coastal flooding and subsequent losses. In this respect, studies on trends, variability and frequency of local extremes and the main forcing mechanisms that can induce surges in the
Mediterranean region already detect changes in the duration and spatial coverage of the storm surges associated with a shift in the location of storm tracks, as in the major sequence of flood events that hit Venice in November 2019 (Cavaleri et al., 2020). The analysis of the distribution of large storm surges events and wave activity, especially along the coast, is essential for a complete evaluation of coastal risks assessment and management.

Tsunamis are often classified as a low-probability high-consequences natural hazard. Their impact may reach far beyond their source region. This likely happened for the 365 Common Era (CE) Crete event, which caused widespread destruction. Tsunami impact may be combined with the seismic shaking, like in the case of the 1908 Messina and Reggio Calabria event; it may also trigger cascade effects such as the so-called NaTech (Natural hazard triggering Technological disasters) events, like the 2011 Fukushima nuclear accident. Past tsunamis in the Mediterranean Sea are well documented (Maramai et al., 2014). In recent years, several small to moderate tsunamis have occurred in the Mediterranean region. A significant tsunami triggered by an earthquake of magnitude 7.0 (USGS) occurred off Turkey's Aegean coast and north of the Greek island of Samos on 30th October 2020. One person was reported to have drowned in Sığacık (Turkey) during the event. In addition, damage was reported to cars and small vessels that were swept away by the waves in Vathy, Samos. In south Chios Island (Greece), a few boats were crushed on the breakwater (Triantafyllou et al., 2020). These events are a reminder that the Mediterranean region is prone to tsunamis. There is now the unique occasion of exploiting a recent fully probabilistic hazard assessment (Basili et al., 2021) to inform disaster risk reduction actions, such as long-term coastal planning, awareness raising, and evacuation planning in support of the tsunami warning and mitigation system (Tsunami Early Warning and Mitigation System in the North-eastern Atlantic, the Mediterranean and connected sea - NEAMTWS, www.ioc-tsunami.org).

In terms of seafood and resource safety, the Mediterarranean Sea harbours more than 80 microalgal species that produce potent toxins, which can cause an array of different human syndromes thus hampering aquaculture activities or result in fish and shellfish kills (Zingone et al., 2021; Quero et al., 2015; 
Garcés et al., 2003; Garcés et al., 1999). Possible intoxications and other adverse effects on human health and seafood may be kept under control through increased monitoring activities which are in place in several countries. However, an even higher impact on the use of marine resources and tourism derives from other types of $\mathrm{HABs}$, such as seawater discolorations caused by high biomass blooms and mucilages, which pose economic activities and wellbeing at risk in many coastal Mediterranean areas.

Natural hazards are further amplified by coastal erosion, which in Mediterranean countries has been primarily driven by human interference with natural processes, such as depletion of terrestrial sediment supply or coastal protection elements. Notably, the only existing surge barrier in the Mediterranean basin has been installed in Venice (Umgiesser, 2020). Conversely, submerged breakwaters can reduce wave energy and mitigate erosion and are becoming a common practice in the Mediterranean region. At the same time, interconnections between different types of hazards need to be addressed in research, planning and management for adaptation, as exemplified by the DANUBIUS-RI platform designed to support interdisciplinary research on rivers and seas by facilitating monitoring within various aspects of environmental, social and economic sciences.

Greater safety with respect to the ocean hazards may be achieved only through the implementation of science-based risk reduction. A multi-disciplinary approach towards observing, monitoring and modelling is expected to trigger synergies and foster a more effective and sustainable long-term management and development; know-how transfer within the contributing research community and beyond is needed to build-up on past and present relevant Mediterranean initiatives.

\section{A sustainably haRVested AND PROductive Mediter- RANEAN SEA}

The Mediterranean blue economy, pivoting the growth of coastal communities and countries, has been characterized in the last years by a constant growth, if not a rush, often affecting the ecosystems' goods and services (e.g., natural capital, landscape, food) on which it is based and from which it is sustained.
For instance, fisheries and aquaculture represent two key sectors for the regional economy with total estimated revenue of US\$ 12 billion, 100,000 operating vessels, including small boats, and 1 million direct and indirect jobs, according to the General Fisheries Commission of the Mediterranean of the Food and Agriculture Organization of the United Nations (FAO). But overexploitation, also due to Illegal Unreported Unregulated (IUU) fisheries, pose the sector at risk. Though 75 percent of assessed stocks remain overexploited in 2018, management strategies put in place in the last years are showing encouraging results, with a decrease of 13 percentage points in six years and a correspondingly decreasing exploitation ratio (FAO, 2020). Even more encouragingly, Mediterranean countries have set forth their intent towards strengthening fisheries management and governance by the signature of the Medfish4ever declaration (Medfish4ever, 2017).

Strong interactions and cross-feedback among sectors (e.g., fisheries and aquaculture, tourism, transport, energy, food, conservation, cultural heritage) adds further complexity in the Mediterranean area due to the conflicting use of the limited available space. The "Knowledge Catalogue" for Maritime Spatial Planning (Kannen et al., 2016) promotes the connection of existing geoportals, from national to European to international, on environment and human activities, to support the management of maritime space and to feed at EU level the definition of national plans, complying with the Directive on Maritime Spatial Planning (Directive 2014/89/EU).

In perspective, the potential of Mediterranean blue economy is considered high, triggered also by emerging technologies and technologically advanced applications, such as marine renewable energies that despite a still low commercial development will be the key to support the energy transition phase.

The development of a sustainable productive Mediterranean Sea and equitable prosperity of the area (Stuchtey et al., 2020) lies more than ever in understanding the interactions and interdependencies of the environmental conditions and processes, the use of resources and the economy: on one side, the potential impacts from established (e.g., extraction of marine living resources, offshore oil and natural gas, ports warehousing construction of water projects, shipbuilding and repair, 
maritime transport, coastal tourism) and growing (renewable energy, blue biotechnology, deep-sea mining, desalination, coastal and environmental protection, defence and security, marine research and education) sectors and pressures on ecosystems and natural resources; on the other side, the potential impacts from environmental changes on the established and emerging maritime industries and their ability to generate growth.

Science-based safe and sustainable thresholds for economic operations in the Mediterranean Sea must drive the sustainable exploitation of renewable and non-renewable resources and the resources based on the Mediterranean Sea natural and cultural heritage, in the framework of effective marine spatial planning and coastal zone management implementation and of the harmonized implementation of regional and sectoral policies on marine and maritime domains.

Despite many countries and regions are now assessing the potential economic value of their resources, also with the support from the European Commission, through specific financing programme, a major limit to guarantee the long-term capacity to sustain such economic activities is represented by the lack of homogeneity and a poorly managed overall use of diverse and numerous resources (Francocci et al., 2019).

\section{A transparent and accessible Mediterranean Sea}

In the last years, with the advent of new technologies, the way in which data have been produced and used has changed. As a consequence, data have become a tradable and valuable good. The new frontier to make data accessible is the development of the data ecosystem. A data ecosystem is a collection of infrastructures, analytics, and applications used to capture and analyse data. The term ecosystem is used because, like real ecosystems, data ecosystems are intended to evolve over time. And this is the case for earth observation data systems, which rather than a new data portal, is intended as a global data ecosystem of existing infrastructures that allows distributed resources to interoperate, and where users have access to any of these resources through the interface of any component.

The European Union invested in policies and infrastructures to make knowledge of the ocean central to environmental and climate policies as well as the blue economy. Its Member States, together with neighbours, have created during the last 20 years an unrivalled marine data and forecasting infrastructure through the European Research Framework Programmes FP6, FP7 and Horizon 2020, the Marine Knowledge Strategy and Copernicus. Working together, the principles of free and open access, of FAIR (Findable, Accessible, Interoperable, and Reusable) data (Wilkinson et al., 2016), and the "measure once, use many times" principle, largely promoted through, have demonstrated clear value. Adhering to the FAIR principles with free, timely, and unrestricted access to ocean observation data is beneficial for the originators, has obvious benefits for users, and is an essential foundation for the development of new services made possible with big data technologies (Tanhua et al., 2019). SeaDataNet, the pan-European infrastructure for ocean and marine data management, is a unique example of the association of connected data centres collectively working to improve the quality and effectiveness in the management, the processing, and the dissemination of oceanographic data at national, regional and global levels, in line with FAIR principles. The EMODnet with its seven disciplinebased thematic portals expanded and extended the partnership to over a hundred and fifty organisations working together to assemble marine data from diverse sources and resources to make them more accessible and more interoperable. EMODnet adopted SeaDataNet tools and services and worked in synergy to adapt the existing data infrastructure to the new data types and technologies. The collaboration of EMODnet is providing a good example of how to build partnerships to fully exploit the marine data value chain and this could contribute to the decade objectives (Martín Míguez et al., 2019). Collaborative working services (Virtual Research Environment) that provide open and free access to data and tools for research will contribute to enhance scientific and educational capabilities getting maximum value from data and, at the same time, to reduce the inequity between northern and southern countries, which is particularly noticeable in the Mediterranean region. The European Commission is providing data and information products and services to monitor our human activities, planet and environment. As far as the ocean is concerned, two Directorates-General of the European Commission, i.e. Defence, Industry and Space (DEFIS) and Maritime Affairs and Fisheries (MARE), are supporting complementary initiatives: the Copernicus 
Marine Service and EMODnet that both distribute open access marine data, interoperable and free of charge. DG DEFIS and DG MARE have signed in 2016 and then in 2019 a Memorandum of Understanding to closely collaborate in data management, data validation and product generation. In practice, the Copernicus Marine Service and EMODnet are joining forces at coordination and operational levels to emphasize the complementarity of their respective marine data offerings.

Nevertheless, there are still large omissions in the available data and monitoring gaps at the basin scale. The SeaDataNet database content shows more than 357,000 data sets (see Figure 6) in the Mediterranean Sea from different disciplines and parameters (bathymetry, physics and biogeochemistry), $79 \%$ of which are open access (Figure 6A) while $21 \%$ are still restricted (Figure $6 \mathrm{~B}$ ). The percentage of unavailable data is constantly decreasing thanks to the increasing trust for data infrastructures, new European incentives towards Open Science and available tools, like persistent identifier to allow acknowledge scientists as well as institutes thanks to the citation index assigned to the data sets. While technology transfer allows less developed countries to reach equal opportunities and results, shared developments and responsibilities allows raise awareness on common goals. Data policy should consider the variety of data types and sensitivity of information. The percentage of restricted data and their provenance can indeed be continuously monitored through metadata, directly from the web portals. The largest percentages with the respect to the relative amount of shared data are from Tunisia (93\%), Morocco (87\%), Slovenia (50\%), Spain $(44 \%)$, Turkey $(40 \%)$, to reach the minimum value of France $(3 \%)$, which is the country that after
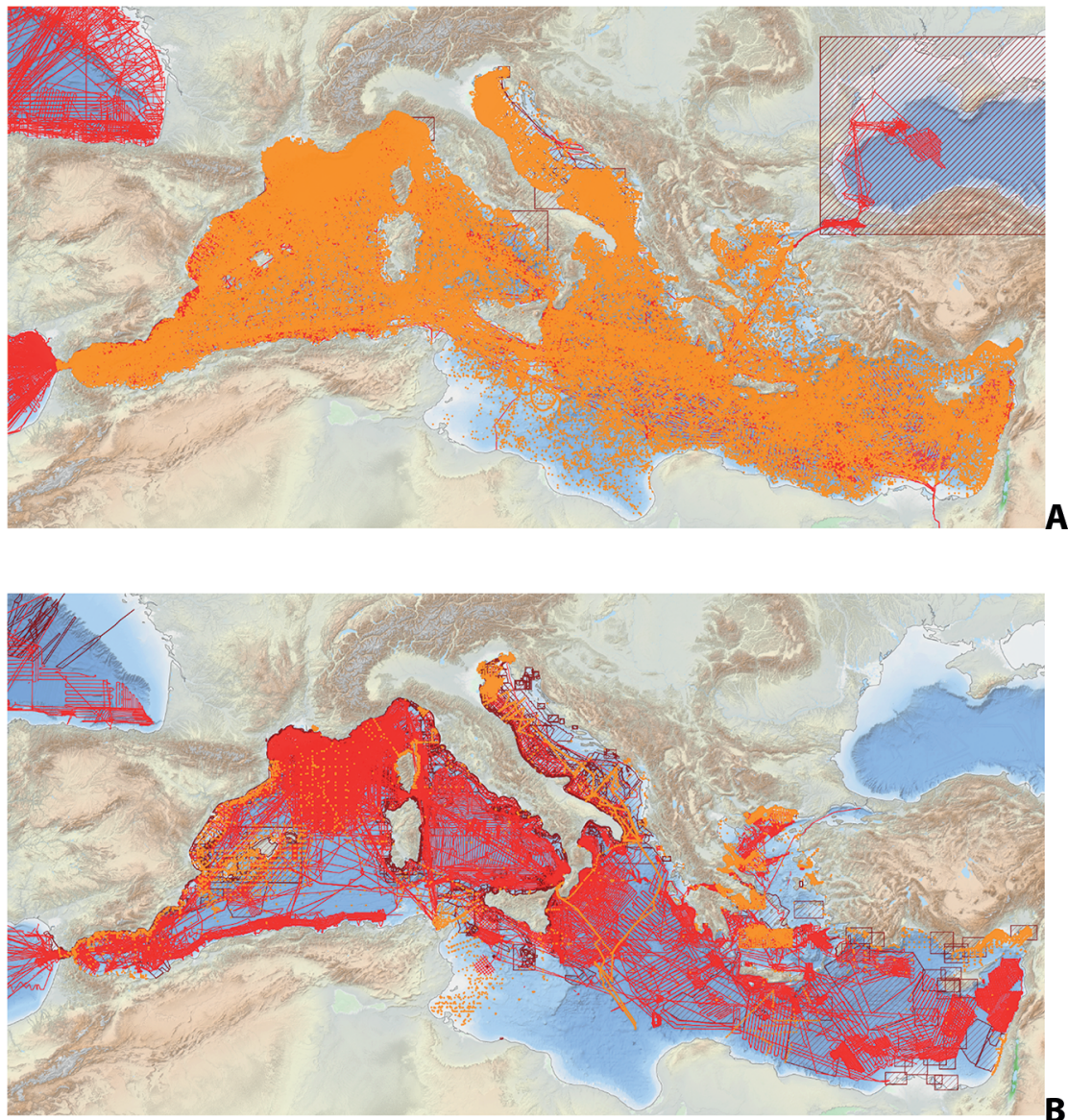

Figure 6. Maps of the open access $A$ and restricted access B data sets available from SeaDataNet data access service (https://cdi.seadatanet.org/search). 
Italy contributes the most. Another interesting piece of information is that the percentage of restricted temperature and salinity data is still too high among EU countries (i.e. $25 \%$ for Italy, $38 \%$ for Spain, $11 \%$ for Greece) with respect to other parameters even if they are not considered as sensitive ones. The spatial distribution of observations in Figure 6 calls attention to where omissions and gaps locate: along the southern coasts, mainly between Tunisia and Egypt, along Turkish and Croatian coasts and in most of the Sicily Channel.

Both maps and statistics indicate a gap between EU and non-EU countries in monitoring and data sharing capacities that appear as North-South and WestEast data distribution differences. This pattern reflects the geopolitical situation of the Mediterranean region and the disparity in access to funding, technology and education in ocean science, which might be faced building trust among the riparian countries and with the EU through multilateral agreements and long-term collaborations on data sharing which include capacity development and appropriate technology transfer in order to be effective. The Global Ocean Science Report (IOC, 2020) provides a baseline for the forthcoming Ocean Decade, assessing the status of the global ocean science economy in the broader context of valuation of ocean spaces (and its uses) and resources.

Blue economy developments on the marine environment and spatial planning requires to have access to information that are rarely collected by the science community. To this end, data from many sea-based sources involving the private sector, which collects a relevant amount of monitoring data on both ante and post-operam phases, need to be made available as raw data and not only in summary reports, to complement sources, in particular land-based, adequately monitored by public authorities. These data need to be integrated in the present data sharing infrastructures.

This requires new legislation to commit all Mediterranean countries and stakeholders, to cooperate in sharing data and monitoring efforts should be faced at the science-policy interface and bring about a new concerted data policy. Challengingly, the foundation of such a process is political stability needed to guarantee continuity.
Finally, the Ocean Digital Twin (ODT) is now emerging as digital framework, in the broader context of the Earth twin (Bauer et al., 2021) and taking inspiration from the urban intelligence cities' model (Castelli et al., 2019), to continuously collect, analyse and visualise marine information. The integration of vast amount of available oceanographic and biochemical data, modelling and simulation along with high-performing computing (HPC) and Artificial Intelligence (Al) enables to study the ocean as a complex system including the relations among the different components (morphological, geological, chemical, physical, biological, socio-economic of coastal communities). As a tool that 'follows' the real dynamic evolution of the system with increasing accuracy, Digital Twin technology enables users not only to develop knowledge to support interventions and solutions, including preventive actions, but also to explore and understand the consequences towards a dynamic ocean management.

\section{An inspiring and engaging Mediterranean Sea}

'An inspiring and engaging ocean' refers to Ocean Literacy and societal engagement. Closely interlinked, they are both required for bringing science (its findings or needs) closer to society and its many actors and sectors, and society, its economy and culture - closer to science.

Ocean Literacy provides the needed platform for multi and transdisciplinary collaboration and a common language to build and reinforce relationships, develop capacities, and connect experts, stakeholders, and society around the topics of sustainable development. Intertwined with societal engagement, it has the potential to enrich various sectors of society in solving sustainability challenges and meeting its opportunities as well as to build a legacy of dialogue, understanding, a cross-fertilization. This is particularly important in a region as the Mediterranean where multi-cultural experiences and remarkable NorthSouth unbalances, including education and gender, co-exist.

Recognizing Ocean Literacy as a key enabler of sustainable management of the human activities in the ocean, IOC has built a global Ocean Literacy portal to bring the Ocean Literacy narratives to a wide range of societal actors, from policy to education. At the 
regional level, the European Commission's EU4Ocean Coalition (https://webgate.ec.europa.eu/maritimeforum/en/frontpage/1482) is being developed as a platform for European citizens, scientific, industry, and education actors to co-develop Ocean Literacy actions. Ocean Literacy is also being addressed by different sectors, from academia to industry, education, and science. Networks like the Consortium for Ocean Science Exploration and Engagement (COSEE) or European Marine Science Education Association (EMSEA) have been fostering Ocean Literacy with an emphasis on education. Industrial organizations and clusters, e.g., TMA BlueTech ${ }^{\mathrm{TM}}$, have been promoting the importance of Ocean Literacy for sustainable blue economy and maritime careers. Scientific associations, e.g., EuroGOOS, have been empowering scientists as Ocean Literacy stewards. Art institutions, e.g., TBA21's Ocean Space, have been promoting the mutually enriching and ever-expanding connection between science and art.

In the Mediterranean, activities related to Ocean Literacy, environmental education, and education for sustainable development have been developed and implemented by scientists and educators who have joined forces to adapt the seven essential Ocean Literacy principles to the Mediterranean region. The EMSEA Med-Working Group delivered the "Mediterranean Sea Literacy" (MSL) guide, comprising seven principles and 43 concepts, all adapted to the specificities of the Mediterranean region (Previati et al., 2018; Realdon et al., 2018). The MSL principles and concepts, serving as guidance for educators, teachers, scientists, non-governmental organizations, policymakers, blue economy sectors, and the general public, are expected to raise awareness towards a Mediterranean-Sea-Literate society (Mokos et al., 2020). Ocean Literacy is also a key asset of several regional initiatives, programmes on education and capacity building, e.g., Mediterranean Strategy and Action Plan for Education for Sustainable Development, Mediterranean Education Initiative on Environment and Sustainability (MEdIES), as well as of universities' networks, e.g., Euro-Mediterranean University (EMUNI), Union of Mediterranean Universities (UNIMED), European University of the Seas (SEA-EU).
An important target for the Ocean Literacy in the Mediterranean is the engagement with traditional and local knowledge holders as essential partners in the understanding of phenomena and the definition of solutions to the environmental challenges. An example from fishery research demonstrates how the ecological knowledge of fishers can help track the geographical expansion of both native and exotic fish species (Azzurro et al., 2011; Boughedir et al. 2015) and fill data gaps in the distribution of exotic species (Elbarassi et al., 2014). These types of initiatives will have to be increased and intensified also through marine citizen science activities.

In terms of societal engagement, citizen science represents a promising way to address current ocean knowledge gaps and build capacities for governments and communities to enable conservation action worldwide (Kelly et al., 2020). Participation in marine citizen science actions has proven to enable communities to engage with the ocean and inform themselves (and potentially their wider social networks) on topics such as ocean and climate nexus, marine species redistributions, plastic pollution, and marine environmental planning, among many others. Still, the ability to make it visible, the evolution of spots, such as the sea floor, commonly hidden to nospecialists but increasingly impacted by human activities is insufficient (Pierdomenico et al., 2019; Madricardo et al., 2019).

Community-based citizen science efforts can also enable a more efficient science-society-policy interface. Stakeholders' mobilization, including around the Ocean Decade, has been promoting a better understanding of the Mediterranean environmental issues and the importance of ocean science to find solutions. Ocean-focused education and a sense of personal attachment are integral to the development of marine citizenship (Mckinley and Fletcher, 2010). Bridging the Mediterranean communities together around the topic of Ocean Literacy will contribute to the shared feeling of ocean citizenship and stewardship in the region. To this end, it will be of outmost importance for the numerous organizations and networks working on marine issues in the Mediterranean to develop and coordinate engagement strategies and capacity development programmes to broaden engagement with stakeholders and societal actors in the region. 


\section{KEY SCIENCE AND CAPACITY DEVELOP- MENT NEEDS: FROM GAPS TO CHALLENG- ES AND OPPORTUNITIES}

The key issues under attention by the Mediterranean science community have been examined in the previous paragraphs in relation with the seven Decade outcomes. While specific science and capacity development gaps and needs can be associated with each of them, new opportunities open-up by meeting them with a cross-cutting approach. Table 2 provides a synoptic overview of the main gaps for the seven Decade outcomes in order to allow an immediate comparison of the interrelation between each of them. The complexity of the issues to be tackled makes it clear that they cannot be addressed by science and technology alone while science-informed governance measures need to be put in place.

In particular, considering its highly polluted status, to secure a clean Mediterranean Sea, the specific gaps, reported in Table 2, need to be overcome. Critical research priorities include: describing the cycle of plastic with consideration of specific Mediterranean issues (deficient wastewater treatment plants-WWTPs, maritime/fishing sources, etc.); acquiring a more comprehensive set of data in order to assess accurately trends for nutrients/eutrophication; considering point sources of priority, emerging contaminants (land based run-off, atmospheric deposition), and contamination schemes (ship emissions, impact of tourism, etc.). In addition, other pathways of contamination or changes in the environment, which relates to more global problems like acidification, may have regional specificities and patterns to be understood.

The challenge of pollution reduction is also part of future integrated observing and forecasting systems, coupling earth system predicting models and tailored end-user products for societal benefit (Tintoré et al., 2019).

Finally, while relevant frameworks are in place to allow synergistic operations (e.g., the Integrative Methodological Framework (IMF) produced by the Priority Actions Programme Regional Activity Centre (PAP/RAC) of UNEP/MAP, the Intergovernmental Hydrological Programme (IHP) of UNESCO, EC and Global Water Partnership-Mediterranean (GWPMed)), appropriate governance is still needed, overcoming the lack of adequate and persistent political commitment, "silo" effects and fragmentation in administrations, overlapping mandates and difficulties in meaningfully transposing international commitments into national and local legislative frameworks and practices.

A better interoperability and integration between existing data and databases (Programme for the Assessment and Control of Marine Pollution in the Mediterranean-MEDPOL, EMODnet, national databases, etc.), and information from scientific work or environmental assessments, would improve the science-topolicy agenda and will enable to tackle the challenge of developing new monitoring indicators, defining thresholds and baseline levels, harmonizing procedures to implement policies and management. Cooperation opportunities are offered at first by the Ocean Decade agenda, which clearly define objectives for marine pollution, including those of SDG14: Life below Water. At regional scale, coordinated actions to assess the state of the environment and reduction measures, such as those by UNEP, add since many years to National Action Plans. Furhtermore, regional and EU initiatives such as the BlueMed Pilot Action for a healthy-plastic free Mediterranean Sea, the zero-pollution plan from the "Green Deal", the Horizon Europe Mission Starfish 2030 (EU, 2020) and relevant European directives, offer opportunities to support actions on the reduction of pollution and monitoring activities of European Member States and neighbours.

The resilience of the Mediterranean Sea cannot be unlimited and will not "buffer" all the threats, since already reacting to the climate change, acidification, extreme events, accidents, overfishing, adding to accumulated pollution. To reach and keep $a$ healthy and resilient Mediterranean Sea the following gaps, hinted in Table 2, need to be addressed for protecting, monitoring, assessing and modelling the ecosystem.

- Ecosystem protection. Marine Protected Areas (MPAs) are lacking enforcement and effective management, often restricted to shallow coastal areas, and poorly integrated in the wider social and economic environment (e.g., Amengual and Alvarez-Berastegui, 2018; Boero et al., 2016). Furthermore, at the MPAnetwork level, the main gap is the low ecological representativity and connectivity (Guidetti et al., 2013; Jenkins and Stevens, 2018). Bridging these gaps, beside increasing knowledge on climate change impacts 
Table 2. Specific scientific and capacity development gaps for the seven Decade outcomes (grey circle with white cross) and main interrelations for each of them (grey circle).

\begin{tabular}{|c|c|c|c|c|c|c|c|}
\hline & 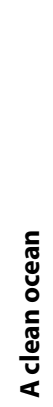 & 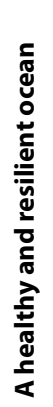 & 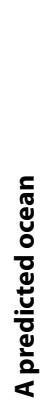 & 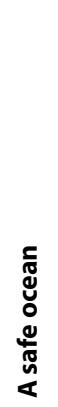 & 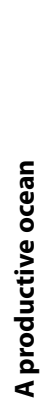 & 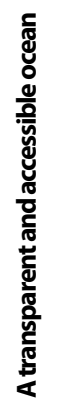 & 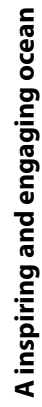 \\
\hline GAPS & & & & & & & \\
\hline $\begin{array}{l}\text { Understanding of primary sources and pathways for the transport of pollutants, } \\
\text { including the mapping of pollution hot-spots and their impacts on ecosystem } \\
\text { and human health, as well as link with social and economic activities. }\end{array}$ & & & & & & & \\
\hline $\begin{array}{l}\text { Linking pollutant fluxes with economic sectors, identifying monitoring } \\
\text { indicators and implementing the planning/management measures of the } \\
\text { entire water cycle for the terrestrial components, based on appropriate science } \\
\text { and technology, as well as all available science/policy interaction. }\end{array}$ & & & & & & & \\
\hline $\begin{array}{l}\text { Better understanding of physical/biogeochemical/biodiversity dynamics } \\
\text { on climate time scales, adopting a comprehensive ocean observing system } \\
\text { (protection/monitoring), improving the quantitative knowledge of ecosystems } \\
\text { (assessing/modelling) and their functioning (including organismal response to } \\
\text { environmental stressors) as the basis for their management (increasing MPAs } \\
\text { level, integrating MSP and ICZM) and adaptation. }\end{array}$ & & & & & & & \\
\hline $\begin{array}{l}\text { Ensuring systematic observations and continuity of data records in north } \\
\text { and south of the Mediterranean and extending the range of observations } \\
\text { to include biological and ecological EOVs also in coastal area and including } \\
\text { novel observations on marine ecosystems to higher trophic levels, fisheries, } \\
\text { genomics, pollutants. }\end{array}$ & & & & & & & \\
\hline $\begin{array}{l}\text { Monitoring the coastal-open ocean exchange, mesoscale and sub-mesoscales } \\
\text { dynamics on ecosystem functioning and the sea floor morphology in four } \\
\text { dimensions in areas characterized by natural (i.e. coastal erosion, deltaic } \\
\text { deposition, mass transport) or anthropogenic modification (i.e. infrastructures, } \\
\text { dredging). }\end{array}$ & & & & & & & \\
\hline $\begin{array}{l}\text { Adopting numerical models which serve to extrapolate observations in both space } \\
\text { and time at the resolution required to understand the coastal and nearshore marine } \\
\text { areas and which include marine ecosystem processes and components needed to } \\
\text { understand the dynamics of coastal and nearshore marine areas, also nested with } \\
\text { open sea models. }\end{array}$ & & & & & & & \\
\hline $\begin{array}{l}\text { Better understanding of the interactions and interdependencies of the } \\
\text { environmental conditions and processes, the use of resources, the economy } \\
\text { function and sustainability at the ecosystem level (rather than at the species level) } \\
\text { and of the inter-relationships between species. }\end{array}$ & & & & & & & \\
\hline $\begin{array}{l}\text { Data availability by exploiting the synergy of in situ and space observation and } \\
\text { forecasting to predict Mediterranean coastal areas in support of multi-hazard early } \\
\text { warning systems and of modelling the effects of the mutual interaction of various } \\
\text { sources of hazards and environmental changes. }\end{array}$ & & & & & & & \\
\hline $\begin{array}{l}\text { Understanding of the seasonal and interannual variations of HABs events and } \\
\text { the changes in their intensity and distribution at the local and regional scales. }\end{array}$ & & & & & & $x$ & \\
\hline $\begin{array}{l}\text { Adequate awareness and involvement of decision makers, communities, citizens, } \\
\text { teachers, media, to influence behaviors and perceptions of different actors towards } \\
\text { effective sea actions (sensu Ocean Literacy). }\end{array}$ & & & & & & & \\
\hline
\end{tabular}


for adaptive management, would promote inclusive and participatory MPA planning and management processes engaging local socio-economic stakeholders such as fishermen and tourism actors, etc.), as well as trigger the methodologies to demonstrate and measure MPA connectivity, at the Mediterranean level.

- Ecosystem monitoring. Gaps in the integration of all spatial planning and management measures taken under various policies (Fisheries, MPAs, Agriculture) have to be filled (Qiu and Jones, 2013) by incorporating Integrated Coastal Zone Management (ICZM) and MSP with other initiatives present in the region and enhancing the capacity on national institutions and experts to effectively monitor, detect and predict climate change scenarios and impacts in the marine ecosystems (Capotondi et al., 2019), reaching a deeper knowledge on species tolerance to warming, pollution, biological invasions, with a focus on endemic, keystone and engineering species (e.g., Pazzaglia et al., 2021; Pérez-Portela et al., 2020). Establishing mechanisms to exchange experiences and disseminate knowledge, information, best practices and training on the new products are meant to support the creation of a Mediterranean marine science partnership for a concerted dialogue between the scientific community, the industry and policy makers.

- Ecosystem assessment. MFSD provides a framework for implementation of a standardized approach, as quantitative as possible, aimed at a coherent representation of the GES, and the 11 MSFD qualitative descriptors drive EU Member States to identify concrete elements to define GES in practice. The Barcelona Convention EcAp roadmap have also adopted a list of 11 Ecological Objectives, (www. unenvironment.org/unepmap/what-we-do/ecosystem-approach) addressing all key elements of the Mediterranean marine environment, further broken down into Operational Objectives COP 17 Decision IG.20/4 (UNEP(DEPI)/MED, 2012), as well as GES definitions and associated targets (COP 18 Decision IG.21/3 (UNEP(DEPI)/MED, 2013). It is crucial to assess marine biodiversity status by integrating state descriptors relating to specific environmental components, such as D1. 'Marine biodiversity', D4. 'Marine trophic network', and D6. 'Integrity of the seabed' (Hay Mele et al. 2020) - and pressure descriptors - closely connected to the status descriptors, such as D3. 'Selective extraction of species' (e.g., Gascuel et al. 2016).

- Ecosystem modelling. Increasing the situational awareness of coastal seas at the scale of cities and urban areas will allow targeting the land-sea interface (Todd et al. 2019), by integrating models focusing on the 'river-sea continuum,' 'estuary models' (simulating the freshwater release on the sea and the salt intrusion into the land), 'storm-surge' models (coupling hydrology and wave/tidal dynamics) and, under a holistic perspective, 'Lagrangian particle models' suitable for predicting the transport of pollution and sediments originating from land and to study ecological connectivity (Falcini et al 2020).

The gap analysis opens a perspective on the following emerging challenges:

- developing more comprehensive ecosystem models and integrating them with novel observation types, including combined satellite and in situ measurements, ocean gliders and Argo floats (Terzic et al., 2019; Chai et al., 2020), animal tracking networks, marine biodiversity observation networks (Moltman et al., 2019), genomic data (Valentini et al., 2016; Fanelli et al., 2020) and more (Benedetti-Cecchi et al., 2018);

- putting into practice lessons learned from the first cycle of application of MSFD (ended on 2020) and expanding the array of relevant, unconsidered descriptors (e.g., Caruso et al., 2016), including the selection of a new generation of early warnings indicators (e.g., Traboni et al., 2018).

- empowering coupled observational and predictive tools, by promoting a downscaling from the global to the regional dimension, as well as enhancing regional mapping of pollution hotspots (oil spill and plastic), as mentioned above, and hazards to drive proactive responses (e.g., translocation of aquaculture plants).

In this framework, establishing mechanisms to exchange experience and disseminate knowledge, information, best practices and training is a not to be missed opportunity meant to support the creation of a Mediterranean marine science partnership for a concerted dialogue between the scientific community, the industry and policy makers, in line with the SDG17: Partnership for the goals.

As reported in section 2, observations on their own are not sufficient, so the development of observing capacity and its sustainability in the long term will represent a major transversal challenge in 
the coming years for all countries to fully reach a predicted Mediterranean Sea.

To tackle this challenge, the relevant gaps reported in Table 2 need to be addressed at first. A required step forward is the integration of satellite observations with the sparse in situ offshore and coastal observations into $\mathrm{Al}$ and/or numerical models to bring out the synoptic 4D description of Mediterranean (Sammartino et al., 2020) and its marine coastal areas (Melet et al., 2020). Several scientific challenges still exist related to the need of improving the observing capabilities at small spatial and temporal scales, to capture their variability, to improve model-data integration and uncertainty estimation (Tintoré et al., 2019), and to address the biological and ecological dimensions, which are essential components to meet the society demand.

When these challenges will be fully tackled, the Mediterranean observing and forecasting system will serve to provide augmented observations which integrate direct observations (including satellite data) to numerical models leading to climatological descriptions in the long term, supplying the information needed to identify ocean variability in our coastal seas, provide the basis for the scientific determination of environmental thresholds, and of course ultimately support the marine environmental monitoring efforts with the broader view on the state of the marine environment. Moreover, these systems will support the future climate scenarios analysis at the appropriate scales. Further providing open data services in the local scale according to user needs, such a system will finally serve the knowledge-based society and boost the private sector through value addition and innovative smart data application.

Partnerships should be strengthened between the existing research and technology coordination, infrastructure, and observing networks, among others EuroGOOS, including MONGOOS, Global Ocean Observing System (GOOS), International Oceanographic Data and Information Exchange (IODE), and established and developing Research Infrastructures' Consortia (e.g., at European level EMBRC, LTER, ICOS RI, DANUBIUS-RI, EMSO-ERIC, JERICO RI, EURO-ARGO ERIC). They should connect the Mediterranean to the global met-ocean information infrastructures and protocols as well as support the human capacity development by improving skills, such as computational skills in high-performance computing (HPC). The Mediterranean basin has the opportunity to be transformed into an international laboratory for integrated observation and predictive capabilities for the assessment of the impacts of climate change and multi-stressors on the ocean ecosystem and its services. Relying on multi-models and ensembles for the analysis of future trends and climate projections, scientific advice can be provided to policymakers to support the development of a sustainable and science-based blue economy, by elaborating and performing model-based scenario analysis to explore the diverse possible outcomes of different political choices. To define safe and sustainable thresholds for economic operations in the ocean will help policymakers and stakeholders reaching $a$ sustainably harvested and productive Mediterranean Sea implementing a truly sustainable blue economy. New research should develop and flesh out sustainable blue-green growth agendas and link it to efforts in ecosystem protection.

To fill the specific gaps in Table 2, there is the need to: better qualify and quantify the concept of a "productive Mediterranean Sea" and identify sound and applicable sustainability indicators; prevent unsustainable exploitation of marine biological resources that can be improved by acquiring better knowledge on mesopelagic fauna; develop innovative aquaculture solutions (i.e., Integrated multi-trophic aquaculture-IMTA, offshore, multi-use) and effective early warning systems to manage food security risks; improve public and private partnership to fulfil Environmental Impact Assessment procedures which require monitoring programs to be planned and implemented (Gonzales et al., 2015). The contribution of private companies to environmental data collection, rare in the past, is the key to support prediction and mitigate the climate change impacts on population and blue economy. For example, renewable energy installations are considered to play a major role in order to meet the commitments of Paris agreement on Climate Change. Maritime archeology and cultural heritage also represent an emerging opportunity that involves monitoring data to assess the level of conservation, a chance for fruition and study of the past.

One main priority for the region is the necessity to move from hazard- to impact-based forecasting in order to better quantify and communicate economical and societal impacts of direct and triggered hazards. 
For a science-based risk reduction, encompassing uncertainty quantification and management along the entire warning chain is of uttermost importance as well as the improvement of the monitoring capabilities for uncertainty reduction (e.g., Angove et al., 2019), and development of integrated multi-hazard early warning systems within a sustainable infrastructural framework (e.g., All Risk Integrated System TOwards Trans-hoListic Early- enhanced European Natural Hazard Scientific Partnership (ARISTOTLEeENHSP, http://aristotle.ingv.it/tiki-index.php; EPOSERIC, EMSO-ERIC).

In a regime of limited planning, optimal planning of the monitoring networks is required. Increasing data availability calls for the construction of a more efficient, cost-effective and reliable data exchange infrastructure, for the full exploitation of the sources of information, while the enhancement of data, data products software and service integration, provision and maintenance shall be implemented once the systematization of existing data sources has been achieved. For this reason, the integration of the existing observatories and the extension of existing networks for the creation of operative off- and onshore real-time monitoring networks is the mandatory starting point to respond to future needs. Following this and even in parallel, the development of innovative methodological approaches and technologies for monitoring (Global Navigation Satellite SystemGNSS, Earth Observation, cables and smart cables, automatic buoys, e.g., Howe et al., 2019) can bring integrated effort towards better forecasting and uncertainty reduction. Further integration of approaches and disciplines would also maximise the exploitation of the possibilities offered by Al and HPC tools and resources (e.g., The European High Performance Computing Joint Undertaking - EuroHPC, https:// eurohpc-ju.europa.eu).

In this respect, the Ocean Digital Twin scenario opens-up a bunch of opportunities. Through new campaigns in the future, the simultaneous use of networks of physical and biochemical sensors (sensors everywhere), satellite systems, intelligently interconnected underwater systems (e.g., loT and loA, Internet of Things and Internet of Actions respectively), marine vehicles (ROVs, AUVs, gliders, Argo floats, oceanographic vessels), the amount of data made constantly available will increase dramatically.
This data will also - increasingly - have to be rapidly analysed to become input for operating systems and models or processed in near-real time through everywhere computing during the same measurement campaigns, and immediately integrated with already existing information. This will allow both to extract new knowledge and to direct the growth, in an intelligent and targeted way, of new information through new measurements and monitoring to dynamically influence planning and management processes.

To take advantage of these opportunities, available data infrastructures such as SeaDataNet and EMODnet need to be reinforced in the Mediterranean Sea, and the collaboration with CMEMS and Regional Activity Centre for Information and Communication (INFO/RAC) needs to be strengthened. An ecosystem of existing data systems should be built as a bottomup effort that, sustaining its network of interconnected data centers, strengthens its foundations. The roles of the data collectors and data providers are increasingly differentiating and specialising. The entire data processing chain (from the origin to the final aggregation on the data infrastructure) integrates and interoperates. In a transparent and accessible Mediterranean Sea open data quality need to be always ensured. To implement an overarching process to assure good quality of data (Quality Control/ Quality Assurance-QA/QC, provenance, transparency, full metadata description and allowing reassessing and reprocessing capabilities), it is fundamental that the validation process reports back to the data sources that are the main responsible for the "master" copy of the data and are responsible for updating and providing access to its best copy. Closing the validation loop will ensure quality improvement on the long term (Giorgetti et al., 2018).

While increasing data availability opens to new opportunities, specific pre-existing challenges should not be overlooked in the warning chain. For example, despite the upstream component is well in place, early warning for near-field tsunamis characterized by a short lead time as well as for tsunamis of non-seismic origin (landslides, volcanic, meteo-tsunamis) remains problematic. Moreover, the downstream component, that is the "last-mile" of the early warning process, is still far from the final implementation mostly due to the relatively low awareness of the tsunami risk, both of the general population and decision-makers 
(e.g., Cerase et al., 2019). The implementation of the "Tsunami Ready" program is indeed a priority for the IOC during the Decade to strengthen the NEAMTWS. This should go along with the risk-informed coastal management (e.g., Tonini et al., 2021).

In the case of hazards of biological nature, such as those related to harmful algal blooms, habitat destruction and biodiversity loss caused by environmental deterioration, the main limitations stem from the lack of biological data and related observation systems for large stretches of coasts of the northern coasts and for the majority of the eastern and southern Mediterranean coastal areas (Garcés E. and J. Camp, 2012). The focus of future actions in this respect is to improve our understanding of $\mathrm{HABs}$ and of the biological mechanisms underlying them through targeted ecological research based on operative in situ real-time monitoring that integrates indicators derived from multiple methodologies and observational platforms, and on the development of $\mathrm{HAB}$ ecological modelling.

In a multi-hazard and multi-risk perspective, a priority is to develop forecasting and early warning systems, from observation to prediction, at the same time taking advantage and making best use of existing coastal GOOS infrastructure. The detection of early stages of bloom development will facilitate risk assessment and adaptation measures, while forecasting supported by ecological modelling is a requisite for maritime spatial planning. Once again, a better organization of the information and data, so far scattered in a multitude of scientific publications or in monitoring agency reports, is requested to improve our capacity to forecast these events and implement adequate management actions to protect human health and activities.

It is worth remarking that in the Mediterranean, one overarching difficulty for risk management is that multiple human-induced pressures combine with a climate change vulnerability hotspot, e.g., increased storms and storm surges frequency and intensity, warming and marine heatwave, sea-level rise, acidification, enhanced eutrophication, invasive species, biodiversity loss, etc. as reported by Intergovernmental Panel on Climate Change-IPCC (MedECC, 2020). It is therefore necessary to begin considering the local influences of time-dependent hazards in a climate projection scenario.
The tsunami experience with the implementation of dedicated tools such as the "Tsunami Ready" program mentioned above, supporting communication to reach risks' reduction, showcases the urgency of improving Ocean Literacy and Mediterranean Sea science communication, which can be fulfilled pivoting on the global Ocean Literacy framework for the Decade. This framework would harvest the wealth of the ongoing Ocean Literacy efforts globally and provide a voice and shared prioritization mechanisms for the global Ocean Literacy community. In this context, Ocean Literacy activities targeting an inspiring and engaging Mediterranean Sea, with its characteristics and specificities, have the opportunity to further flourish. Finally, in terms of capacity needs for governance to be improved and for science and technology to be properly developed and used, comprehensive education for sustainable development and public awareness are needed, together with closer involvement and collaboration of all stakeholders, including universities and research institutions but also NGOs and civil society organisations at large. The Mediterranean can count on active and resourceful networks as well as many important projects supported by the EU and several donors.

\section{RECOMMENDATIONS FOR SCIENCE-POLICY AGENDA TO ACHIEVE THE OCEAN DECADE OUTCOMES AND FACE ITS CHALLENGES: PATHWAYS FOR SOLUTIONS AND CROSS- CUTTING PRIORITIES}

This paper builds on the findings of the Decade planning workshops for the Mediterranean which took place in 2020, with particular reference to the outputs of the discussion on Decade's outcomes as well as proposals to co-design the activities. Tailored concrete actions recommended under each outcome are presented as preliminary input to feed a major overarching science-to-policy action needed to support a transformation in the Mediterranean. Following a preliminary assessment of the available capacities, the objective is to turn the Mediterranean area into a science hub serving a "model region" where the challenge of strengthening the science-policy-society interface towards reversing the cycle of decline of the marine environment is fully tackled. This effort will explicitly point to the interconnections of pollution, climate change and hazard risk issues with the sustainability of the blue economy. Thus, it will contribute to 
defining prevention, adaptive and mitigation strategies fit for the population. To this end, cross-cutting and regulatory measures need to be undertaken.

To support the reduction of pollution toward $a$ clean Mediterranean Sea the level of intervention should encompass the following general measures: implement and support circular economy; optimize and reinforce monitoring to support SDG 14.1 on "reduce marine pollution"; define operational targets (nutrients and chemical reduction, discharges, single use plastics, extended producers' responsibilities, etc.); introduce risk assessment in pollution assessments in the Mediterranean Sea; promote Ocean Literacy and citizen science. NGOs and civil society play indeed a key role in keeping pollution issues visible with the general public and also on the political agenda, a metaphorically relevant aspect if we consider that pollution is mostly hidden, e.g., in the seafloor. These sectors are key for literacy and influencing behavior modification needed to inform individual choices and environmental responsibility. Any attempts to stem global ocean pollution must deal with these regional land-derived problems as well as addressing urgency. Transportation and sinks are complex and standard guidelines must be established and toxicity understood for setting priorities. There must be an emphasis on controlling sources of pollution beside cleaning. The development of regional agreements and initiatives on sources, sinks, and types of wastes in all countries must also be a priority.

In parallel, the research actions should tackle pollution threats by better understanding the distribution, concentration and provenance of all forms of pollution focusing on source-to-sea and across sectors. This will require to:

- develop, assess and monitor plans of all sources (air/land/sea-based) of pollutants and particularly marine litter, upscaling initiatives for a clean and a healthier sea;

- address eutrophication problem developing advanced Index of Coastal Eutrophication based on in situ and satellite observation and model by determining the maximum inputs of nutrient pollution for each Mediterranean area affected by eutrophication;

- analyse pressures, status, trends and effects of hazardous substance pollution in the
Mediterranean; update the report/map of hot spots of chemical contamination, as well as the Lists of Substances of Possible Concern in the Mediterranean and Chemicals for Priority Action as contribution to existing legislation.

Pollution impact is only one among the Mediterranean Sea stressors. Conservation and protection of marine ecosystems requires boosting interdisciplinary research aimed at elucidating impacts of cumulative stressors on the ocean hence providing more complete information to fill gaps, and specify actions, aiming to improve the situation and reverse the degradation. Completing the science base with holistic mapping of the ocean, in all its dimensions, will also be needed for an adaptive management approach towards good ocean stewardship. The following pathways for solutions are identified to keep a healthy and resilient Mediterranean Sea:

- defining 'restoration' to provide scientific understanding of the future needed ocean state, creating conditions to return the Mediterranean degraded, damaged or destroyed ecosystems to their 'functional historic trajectories';

- understanding of structure and function of the ecosystems, spanning from the surface, through the deep sea, to benthic landscapes;

- understanding relations between reaction norm (environmental tolerance) of ecosystem structuring species and ongoing and predicted climatic changes (predicting species response, migration, and eventually extinction);

- understanding interdependencies between ecosystems across the aquatic continuum by defining baselines for structure and function in the context of understudied biogeochemical cycles, larval dispersal and populations connectivity, migratory patterns and strategies, and their relations to inter-systems links;

- identifying EOVs and sampling issues to better predict distribution and patterns by implying participatory exercises to set priorities for regional mitigation/adaptation plans;

- modelling the abrupt changes and phase shifts in ecosystem states and the impacts of unknown and emerging stressors on ecosystems; 
- enlarging the management vision to the socioecological systems. Develop test cases for ecological theories benefiting from regions with accelerated paths of change and the possibility to work on a high number of diversified ecosystems; perform comparative exercises taking into account multicultural contexts, diversified socio-economic opportunities and the geopolitical diversity; pay attention to land-sea interfaces - including vulnerability;

- evaluate impacts of policy actions on restoration and management to improve understanding of the ecological trade-offs and effectiveness of MPAs to strengthen the application of effective management measures for the protection of the Mediterranean and its biodiversity;

- understanding the effects on the ecosystem of new and cumulative impacts of climate change, the growing blue economy, and geoengineering. Scaling up monitoring actions at the regional scale to collect spatial information on cumulative impacts (including on deep sea environments).

At cross-cutting level, ad-hoc formation programmes on specific mitigation/adaptive strategies addressing urgent, punctual events with high socioeconomic impact (e.g., building up a regional near real time 'warning' platform' for dangerous invasive species) need to be developed and innovative technologies, e.g., related to the effective use of novel resources (particularly invasive species, such as tropical fish and invertebrates, jellyfish and seaweeds as potential food) boosted. Social sciences need to be always integrated.

Advanced monitoring approaches serving a clean, healthy, and resilient basin clearly call for a dialogue with the observing system community responsible to target a predicted Mediterranean Sea.

The current observing and predictive capabilities need to be sustained and to be expanded towards the biological and ecological dimension, in order to be able to observe, assess and predict related properties, as a response to alternative scenarios of climate changes and/or management policies. To address emerging scientific and societal challenges, new Rls need to be developed building on existing successful observational/research infrastructures. Robust linkages between all types of Marine Rls (ships, stations, biology tracking, mesocosms, autonomous: gliders/ floats/AUVs etc.), i.e. connected in a network of networks, should be built. Synergy (capital S) of in situ and space-based observation should be exploited to extend data coverage and to reduce the observational gaps of data between north and south of Mediterranean. Interoperability and opportunity opened by the big data technology will lead to integrated observing systems that are responsive and fit for purpose.

Efforts should be made to support technological innovation in observation and to improve model capabilities to predict the state of the ecosystems by:

- adopting variable spatial and temporal resolutions, according to the scale of the processes, integrating coastal and open sea;

- improving the model capability to use and upload the data coming from the new observing systems;

- integrating different processes in multiple stressors, multiple species, ecological models, hydrodynamic and Lagrangian models;

- taking full advantage of the new observational capabilities offered by present and future space missions to extend the range of observables including biological and ecological EOVs;

- integrating existing models with artificial intelligence ones to exploit big data sets;

- addressing the impact of multiple stressors (anthropogenic \& natural) on ecosystems and coastal dynamics.

A well predicted Mediterranean Sea is a safer one. The integration of observatories and extension of the existing networks and European Research Infrastructures (RIs) will trigger the creation of a joint, open access, offand onshore real-time monitoring network and hence foster the additional capacity building in a trans-disciplinary approach for the benefit of the scientific community and citizens, as well as policy makers, risk managers and stakeholders. This will support the achievement of $a$ safe Mediterranean Sea.

In parallel to the establishment of an observatory network, a data infrastructure also including biological data is needed to allow the development of models, early-warning and forecasting capability. The enhancement 
of forecasting capabilities is of utmost importance. In terms of capacity-building and technology transfer it is essential to encourage scientific networking for multihazard and multi-risk approaches. All that would allow supporting plans for adaptation and mitigation to hazardous events and climate change, to improve the preparedness of the Mediterranean region countries to emergencies, thus reducing the coastal risks, safeguarding population and socio-economic activities at sea, from an integrated perspective.

Low or incomplete and inaccurate risk perception typically leads to lack of informed risk management and of specific regulations. Reckoning these potential pitfalls and drawbacks stemming from risk perception leads to the recommendation for a stronger interaction with social scientists. Education for preparedness and awareness-raising could help trigger a more thorough risk perception and drive policy makers to plan and implement sustainable risk reduction measures.

Uncertainties are not fully considered weakening any long-term risk reduction strategy. Conversely, knowledge transfer to the society would improve risk awareness, assessment, prevention and mitigation, and long-term territorial and infrastructure renovation planning, to meet more adequate safety standards. Communicating uncertainties to stakeholders would make it easier to compare the different risks and to make informed decisions.

In terms of Ocean Literacy and social engagement, the effort to integrate different scientific disciplines, research institutions, European Rls, and stakeholders including marine operators and citizens, shall contribute to raise the societal awareness on the system complexity and the importance of science to better understand the status of marine environment and the difficulty to predict complex impacts of multi-hazards and multistressors affecting the basin, while promoting an integrated coastal and marine planning for risk reduction.

Attention should be also paid to the governance component of the systems, which might need to be transnational and multi-levels. The connection between existing infrastructural initiatives and intergovernmental bodies shall be fostered including a political agenda for prioritization and funding as well as frameworks for cost-sharing a including a political agenda for prioritization and funding as well as frameworks for cost-sharing and partnership.
The whole process shall contribute to narrow the gap between the bordering countries of the basin, with a specific focus on developing countries, fostering an open access approach to observational and monitoring information, which are relevant for the entire Mediterranean Sea.

A shared Mediterranean Sea must be pursued also in terms of data access and transparency. Uptake of data and prediction produced by the system, and delivered in agreement with the FAIR protocols, i.e., findable, accessible, interoperable and reusable for anyone across the basin, should be maximized. Databases must prioritize the acquisition of records on productivity limits and availability of marine resources, but also including socio-economic data. Feedback from users should be considered in system continuous development.

To prevent duplication, the e-ecosystem should aim at connecting data infrastructures, without copying data and creating multiple versions of the same data, disconnected from the original source. The SeaDataNet distributed network of professional data centres, providing on-line integrated access to databases of standardized quality, mark a substantially different approach from the centralised World Ocean Database and guarantee tight connection from the data originators to the final aggregation and delivery of the observations. Additionally, SeaDataNet standards, the access and viewing services, the data formats, the metadata catalogues represent an international reference, reaching the widest adoption with the SeaDataNet Controlled Vocabulary, used in all the continents.

To sustain a robust ecosystem of data infrastructures, national engagement such as commitments from nations to participate in and use the existing data infrastructures is highly expected and recommended. National funding should maintain and update the national contribution to SeaDataNet and EMODnet.

A citation index for data sets (with persistent identifiers) to acknowledge scientists as well as institutes links directly to the repository so that users can quickly access the associated research data. Citations to data sets and studies are indexed so that their impact can be measured and their influence tracked. 
A key recommendation towards a transparent and accessible Mediterranean Sea is to promote partnerships and agreements, in order to capitalize on previous experience and existing capabilities, through integration, consolidation, and enhancing of existing systems and efforts. This includes a fuller connection between experimental and modeler communities, in order to fuel a better connection between the models and the information acquired with novel observation systems. In a forward-looking policy orientation, the envisaged process fosters cost-effective and efficient observational and monitoring infrastructures management and forms a solid basis for further implementations, which will promote the Mediterranean Sea as a relevant science open laboratory at a global scope.

Providing open data services in the local scale according to user needs is the key to serve the knowledge-based society and boost the marine economic sectors through value addition and innovative smart data applications, which along with spatial planning tools will serve $a$ sustainably harvested and productive Mediterranean Sea.

In this perspective, improving our understanding on how the blue economy sectors and climate variability impact on fisheries is the key to promote sustainable exploitation of resources, as the vast percentage of the assessed stocks is currently at an overexploited status. Special effort should be addressed to small scale fisheries, holding an important socio-economic role in the region, and contributing significantly to the structure and development of the Mediterranean coastal communities. In this context, and in collaboration with the General Fisheries Commission for the Mediterranean (GFCM), it is important to define indicators and standards of sustainability, define and study approaches and tools to identify the trade-offs between ecological dynamics and socio-economics needs by taking into account the unique characteristics of the Mediterranean social-ecological systems.

As far as energy supply is concerned, the community has recommended strategies that can help improve our capacity-development, transfer of marine technologies and innovative design solutions to promote energy transition towards renewable resources and decarbonisation, to mitigate climate change effects which are quite pronounced in the
Mediterranean. The promotion of emerging technologies, such as floating turbines and other ocean energy technologies, will improve coexistence and synergies between Offshore Renewable energy (ORE) production and other maritime sectors (e.g., aquaculture, fisheries, tourism, transport, Oil\&Gas, Carbon capture and storage). Thus, new spatial management tools, such as e.g., evaluating conflicts and synergies, single and cumulative impacts, scenario building and analysis, suitability for specific uses, participatory processes and co-design, must be developed and applied to support decision making processes. In particular, they should aim at promoting the integration of MPAs in MSP and coastal management processes and the coherence between maritime and terrestrial planning as well. Moreover, as for the clean Mediterranean target, moving towards bio-economy and a circular economy framework is recommended. Hence new biotechnological solutions must be identified and exploited. Mediterranean maritime clusters (i.e., sectoral and national) shall play a major role in facilitating the exchange of knowledge, communication and best practices between public and private stakeholders and promote entrepreneurship.

The Mediterranean community must move towards the concept of a Mediterranean Sea as a shared sea, promoting the principle of the Mediterranean as "Common Sea", which contains "Common Goods", i.e. the shared and coordinated management of areas under one's own jurisdiction and of resources that have no borders. In such a context, any best practice will have an extra value to address policy and decisions in the future and help promote sustainable and balanced development of sea uses, sustainable tourism models in connection with SSF, cultural heritage, leisure boating and protected areas. Local communities and stakeholders must thus be effectively and transparently involved into national and transnational policy and decision- making processes, with the social science dimension needs to take part into the decision process. The broad community must also promote and inform the development of sciencebased regulatory frameworks and policies.

To reach a shared Mediterranean Sea that is sustainably harvested and productive, collaboration among existing long-term Initiatives (e.g., BlueMed and WestMED), partnerships and institutional networks and Organisations (e.g., Union for 
the Mediterranean-UfM, UNEP, GFCM, Conference of Peripheral Maritime Regions-(PMR) need to be reinforced at basin and sub-basin scale. In addition, improving capacities and skills development of the new generation of marine biotechnologists, engineers, economists, touristic operators, journalists, and marine biologists, could enable future generations to contribute to a truly sustainable blue growth that can only be based on a healthy marine environment.

Outreach and awareness raising must also be pursued. In this context, Ocean Literacy actions must be taken, and we must also operate at the science/ policy interface. The community needs to improve the collaboration with media in order to reinforce the communication with the general public and support science-based policy processes and harmonization, through coordination, effective implementation, optimal institutional design, monitoring and adaptation of existing Mediterranean, European and international policies.

Ocean Literacy and societal engagement have been recognized as recommended cross-cutting themes. The Decade outcome an inspiring and engaging ocean in the Mediterranean should help create a generation of ocean citizens and stewards capable of making science-based decisions for the protection and sustainable use of the marine environment. It will be key during the next ten years to develop actions at multiple levels and involving multiple sectors as a major opportunity to unlock the full value of human interactions, built on respect, equity, and responsibility, boost creativity in the search of ocean solutions to the world challenges, and inspire each other towards the ocean protection for sustainable development.

Recurrently, key cross-cutting recommendations have been addressed. In terms of partnerships, governance platforms for harmonization of national marine strategies of all Mediterranean Countries (e.g., EU Directives and the Barcelona Convention) need to be implemented provided the consolidation of the science-policy interface to ensure that the adopted policy options contain a robust scientific basis and that they are coherent with the SDGs. To improve transboundary partnership, vertical cooperation (coordination between the different administrative level) and horizontal cooperation (collaboration between sectors) should be enhanced.
North-South partnership deserves a specific focus. Strengthening the cooperation between the developed and developing Mediterranean countries represent a critical challenge to moderate the twospeed sustainable development which distinguishes the north and south shores. Capacity building and technology transfer is of utmost importance to foster co-designed scientific research, allocate to local scientists the needed infrastructure to conduct their research, enable policy coherence and the ecological transition in the frame of the SDGs.

Overcoming barriers such as competition, preconceived ideas, multi-stakeholder engagement, financial constraints, capacity issues, will improve transboundary collaboration leading to collaborative and coordinated pan-Mediterranean actions, including governance exercises to tackle complex systems and multi-cultural settings for further modelling and scaling-up.

Regional organizations could play an important role to harmonize capacity building in the region, with consideration to best practices to ensure the high quality of the training courses. Finally, social science is crucial for understanding what actions and behavior modifications would lead to desired outcomes.

\section{CONCLUSIONS}

Despite the progress made during the past years, the Mediterranean Region is still far from achieving and fully implementing the SDGs objectives. Nevertheless, as demonstrated by the previous sections, the state of the art of Mediterranean research and the long-term experience in cooperation of the community further supports the idea of the added value of developing a coordinated Regional Programme in the framework of the Ocean Decade global initiative.

"The Science We Need for the Mediterranean Sea We Want (SciNMeet)" Programme has been submitted in response to the first Call for Decade Actions as concrete proof of the willingness of the Mediterranean community to further cooperate in a global initiative, enhancing synergies and scaling-up relevant achievements reached so far. The Programme, which has been endorsed as Decade Action, aims at triggering a science driven 
transformative change for the Mediterranean region by strengthening the science base related to the effect on marine ecosystems (thus goods and services) of the various stressors affecting the Mediterranean Sea, i.e. climate change, marine pollution from air/ land/sea-based sources and overexploitation of marine resources, as well as of the extreme events threatening people and the environment, such as storms and tsunamis, to envision a sustainable safe and depolluted Mediterranean Sea "climatic system" (the Mediterranean Sea we want). Integration of existing initiatives and organizations and co-design have been adopted to prepare this white paper and to draft the SciNMeet Programme. Building on current relevant Mediterranean initiatives, organizations and cooperation experiences (BlueMed, UNEP/MAP, Interreg-Med, UfM, CIESM, MONGOOS, EuroGOOS, EMODnet, NEAMTWS, European Space Agency-ESA Mediterranean Sea Regional Initiative, etc.), and emerging actors, SciNMeet aims to address Decade basin challenges with a multidisciplinary, cross-sector approach, further engaging in particular the private sector. Transboundary cooperation will be pursued, and capacity development enhanced, in order to narrow the present North-South gap.

This paper has to be considered as the first step towards the preparation of the SciNMeet Implementation Plan; the second step will be to identify the projects that will contribute to the Programme since the starting time and to quantify the cost of the activities and the source of funding to contribute to its implementation in the short and long run.

On financing and support, dedicated regional funds (e.g. European Territorial Cooperation Interreg MED), European and the global-scale one (World Bank, United Nations Development Programme-UNDP) need to be integrated to complement national investments. Mobilize financing, having the Ocean Decade visible in the national agenda, enhance national implementation and strengthen institutions are the key to achieve the Goals by the target date of 2030, leaving no one behind.

\section{AUTHOR CONTRIBUTIONS}

Conceptualization: M.C.; R.S.; L.E.

Writing - original draft: M.C.; R.S.; L.E.; F.G.; E.G.; A.G.; F.F.; B.H.; K.H.; S.K.; S.L.; C.S.; M.C.L.; M.C.; D.D.; F.F.;
G.G.; D.M.C.; E.O.; A.P.; G.S.; M.S.; S.S.; A.B.; A.B; D.CS.;V.C.; R.C.; A.D.; S.E.A.; D.E.; M.F.; T.H.; G.P.; F.S.; M.S.; F.T.; L.T.; G.U.; A.Z.

Writing - review \& editing: M.C.; R.S.; L.E.; F.G.; E.G.; D.E.; F.S.; C.S.; F.T.

Resources: T.B.; A.C.; G.C.; S.G.; J.K.; G.L.; J.P.; N.P.; G.P.; M.R.; M.S.; Z.S.; A.S.; M.S.; J.T.; V.V; M.Z..

\section{REFERENCES}

AMENGUAL, J. \& ALVAREZ-BERASTEGUI, D. 2018. A critical evaluation of the Aichi Biodiversity Target 11 and the Mediterranean MPA network, two years ahead of its deadline. Biological Conservation, 225, 187-196.

ANDROULIDAKIS, Y. S., KOMBIADOU, K. D., MAKRIS, C. V., BALTIKAS, V. N. \& KRESTENITIS, Y. M. 2015. Storm surges in the Mediterranean Sea: variability and trends under future climatic conditions. Dynamics of Atmospheres and Oceans, 71, 56-82.

ANGOVE, M., ARCAS, D., BAILEY, R., CARRASCO, P., COETZEE, D., FRY, B., GLEDHILL, K., HARADA, S., VON HILLEBRANDT-ANDRADE, C. KONG, L., MCCREERY, C., MCCURRACH, S. J., MIAO, Y., SAKYA, A E. \& SCHINDELÉ, F. 2019. Ocean observations required to minimize uncertainty in global tsunami forecasts, warnings, and emergency response. Frontiers in Marine Science, 6, 350, DOI: https://doi.org/10.3389/fmars.2019.00350

AZZURRO, E., MOSCHELLA, P. \& MAYNOU, F. 2011. Tracking signals of change in Mediterranean fish diversity based on local ecological knowledge. PLoS One, 6(9), e24885, DOI: https://doi.org/10.1371/journal.pone.0024885

BAN, N. C., GURNEY, G. G., MARSHALL, N. A., WHITNEY, C. K., MILLS, M., GELCICH, S., BENNETT, N. J., MEEHAN, M. C., BUTLER, C., BAN, S. \& TRAN, T. C. 2019. Well-being outcomes of marine protected areas. Nature Sustainability, 2(6), 524-532.

BASILI, R., BRIZUELA, B., HERRERO, A., IQBAL, S., LORITO, S., MAESANO, F. E., MURPHY, S., PERFETTI, P., ROMANO, F., SCALA, A., SELVA, J., TARONI, M., THIO, H. K., TIBERTI, M. M., TONINI, R., VOLPE, M., GLIMSDAL, S., HARBITZ, C. B., LØVHOLT, F., BAPTISTA, M. A., CARRILHO, F., MATIAS, L. M., OMIRA, R., BABEYKO, A., HOECHNER, A., GURBUZ, M., PEKCAN, O., YALÇINER, A., CANALS, M., LASTRAS, G., AGALOS, A., PAPADOPOULOS, G., TRIANTAFYLLOU, I., BENCHEKROUN, S., AGREBI JAOUADI, H., BEN ABDALLAH, S., BOUALLEGUE, A., HAMDI, H., OUESLATI, F., AMATO, A., ARMIGLIATO, A., BEHRENS, J., DAVIES, G., DI BUCCI, D., DOLCE, M., GEIST, E., VIDA, J. M. G., GONZÁLEZ, M., MACÍAS SÁNCHEZ, J., MELETTI, C., OZER SOZDINLER, C., PAGANI, M., PARSONS, T., POLET, J., POWER, W., SØRENSEN, M. \& ZAYTSEV, A. 2021. The making of the NEAM tsunami hazard model 2018 (NEAMTHM18). Frontiers in Earth Science, 8, 616594, DOI: https://doi.org/10.3389/ feart.2020.616594

BAUER, P., DUEBEN, P. D., HOEFLER, T. QUINTINO, T., SCHULTHESS T. C. \& WEDI, N. P. 2021. The digital revolution of Earth-system science. Nature Computational Science, 1, 104-113.

BENEDETTI-CECCHI, L., CROWE, T., BOEHME, L., BOERO, F., CHRISTENSEN, A., GRÉMARE, A., HERNANDEZ, F., KROMKAMP, J. C. GARCÍA, E. N., PETIHAKIS, G., ROBIDART, J., PINTO, I. S. \& ZINGONE, A. 2018. Strengthening Europe's Capability in biological ocean observations. In: PINIELLA, Á. M., KELLETT, P., LARKIN, K. \& HEYMANS, J. J. (eds.). Future science brief 3 - European marine board. Belgium: Ostend. 
BLUEMED COORDINATION AND SUPPORT ACTION. 2018. BlueMed strategic research and innovation agenda. Updated version 2018. Brussels: BlueMed Coordination and Support Action.

BOERO, F., FOGLINI, F., FRASCHETTI, S., GORIUP, P., MCPHERSON, E., PLANES, S., SOUKISSIAN, T., THE COCONET CONSORTIUM. 2016. The CoCoNet Guidelines. Towards Coast-to-COast NETworks of marine protected areas (from the shore to the high and deep sea), coupled with sea-based wind energy potential. SCIRES-IT (SClentific RESearch and Information Technology, 6, 1-96.

BOUGHEDIR, W., RIFI, M., SHAKMAN, E., MAYNOU, F., GHANEM, R., SOUISSI, J. B. \& AZZURRO, E. 2015. Tracking the invasion of Hemiramphus far and Saurida lessepsianus along the southern Mediterranean coasts: a local ecological knowledge study. Mediterranean Marine Science, 16(3), 628-635.

CANONICO, G., BUTTIGIEG, P. L., MONTES, E., MULLER-KARGER, F. E., STEPIEN, C., WRIGHT, D., BENSON, A., HELMUTH, B., COSTELLO, M., SOUSA-PINTO, I., SAEEDI, H., NEWTON, J., APPELTANS, W., BEDNARŠEK, N., BODROSSY, L., BEST, B. D., BRANDT, A., GOODWIN, K. D., IKEN, K., MARQUES, A. C., MILOSLAVICH, P., OSTROWSKI, M., TURNER, W., ACHTERBERG, E. P., BARRY, T., DEFEO, O., BIGATTI, G., HENRY, L. A., RAMIRO-SÁNCHEZ, B., DURÁN, P., MORATO, T., ROBERTS, J. M., GARCÍA-ALEGRE, A., CUADRADO, M. S. \& MURTON, B. 2019. Global observational needs and resources for marine biodiversity. Frontiers in Marine Science, 6, 367, DOI: https:// doi.org/10.3389/fmars.2019.00367

CAPASSO, A., CAPPELLETTO, M., EVANGELISTA, L., POMARO, A. \& SANTOLERI, M. 2020. UN-decade of ocean science for sustainable development Mediterranean workshop - report. Dublin: CNR ExploRA.

CAPET, A., FERNÁNDEZ, V., SHE, J., DABROWSKI, T., UMGIESSER, G., STANEVA, J., MÉSZÁROS, L., CAMPUZANO, F., URSELLA, L., NOLAN, G. \& EL SERAFY, G. 2020. Operational modeling capacity in European Seas - an EuroGOOS perspective and recommendations for improvement. Frontiers in Marine Science, 7, 129, DOI: https://doi.org/10.3389/fmars.2020.00129

CAPOTONDI, A., JACOX, M., BOWLER, C., KAVANAUGH, M., LEHODEY, P., BARRIE, D., BRODIE, S., CHAFFRON, S., CHENG, W., DIAS, D. F., EVEILLARD, D., GUIDI, L., IUDICONE, D., LOVENDUSKI, N. S., NYE, J. A., ORTIZ, I., PIRHALLA, D., POZO BUIL, M., SABA, V., SHERIDAN, S., SIEDLECKI, S., SUBRAMANIAN, A., VARGAS, C., DI LORENZO, E., DONEY, S. C., HERMANN, A. J., JOYCE, T., MERRIFIELD, M., MILLER, A. J., NOT, F. \& PESANT, S. 2019. Observational needs supporting marine ecosystems modeling and forecasting: from the global ocean to regional and coastal systems. Frontiers in Marine Science, 6, 623, DOl: https://doi.org/10.3389/fmars.2019.00623

CARUSO, G., LA FERLA, R., AZZARO, M., ZOPPINI, A., MARINO, G., PETOCHI, T., CORINALDESI, C., LEONARDI, M., ZACCONE, R., UMA$\mathrm{NI}$, S. F., CAROPPO, C., MONTICELLI, L., AZZARO, F., DECEMBRINI, F., MAIMONE, G., CAVALLO R. A., STABILI, L., TODOROVA, N. H., KARAMFILOV, V. K., RASTELLI, E., CAPPELLO, S., ACQUAVIVA, M. I., NARACCI, M., DE ANGELIS, R., DEL NEGRO, P., LATINI, M. \& DANOVARO, R. 2016. Microbial assemblages for environmental quality assessment: knowledge, gaps and usefulness in the European marine strategy framework directive. Critical Reviews in Microbiology, 42(6), 883-904.
CASABIANCA, S., CAPELLACCI, S., PENNA, A., CANGIOTTI, M., FATTORI, A., CORSI, I., OTTAVIANI, M. F. \& CARLONI, C. 2020. Physical interactions between marine phytoplankton and PET plastics in seawater. Chemosphere, 238, 124560, DOI: https://doi.org/10.1016/j.chemosphere.2019.124560

CASTELLI, G., TOGNOLA, G., CAMPANA, E. F., CESTA, A., DIEZ, M., PADULA, M., RAVAZZANI, P., RINALDI, G., SAVAZZI, S., SPAGNUOLO, M. \& STRAMBINI, L. 2019. Urban intelligence: a modular, fully integrated, and evolving model for cities digital twinning. In: Proceedings of 2019 IEEE $16^{\text {th }}$ International Conference on Smart Cities: Improving Quality of Life Using ICT \& IOT and AI (HONET-ICT) [online]. Charlotte, NC, USA, 6-9 Oct 2019. Charlotte: HONET-ICT, pp. 33-37. Available at: https://ieeexplore.ieee.org/xpl/conhome/8901680/ proceeding [Accessed: March 2021].

CAVALERI, L., BAJO, M., BARBARIOL, F., BASTIANINI, M., BENETAZZO, A., BERTOTTI, L., CHIGGIATO, J., FERRARIN, C., TRINCARDI, F. \& UMGIESSER, G. 2020. The 2019 flooding of Venice and its implications for future predictions. Oceanography, 33(1), 42-49.

CERASE, A., CRESCIMBENE, M., LA LONGA, F. \& AMATO, A. 2019. Tsunami risk perception in southern Italy: first evidence from a sample survey. Natural Hazards and Earth System Sciences, 19, 2887-2904, DOl: https://doi.org/10.5194/nhess-19-2887-2019

CHAI, F., JOHNSON, K. S., CLAUSTRE, H., XING, X., WANG, Y., BOSS, E., RISER, S., FENNEL, K., SCHOFIELD, O. \& SUTTON, A. 2020. Monitoring ocean biogeochemistry with autonomous platforms. Nature Reviews Earth \& Environment, 1, 315-326, DOI: https://doi.org/10.1038/s43017-020-0053-y

CHENG, L., ABRAHAM, J., TRENBERTH, K. E., FASULLO, J., BOYER, T., LOCARNINI, R., ZHANG, B., YU, F., WAN, L., CHEN, X., SONG, X., LIU, Y., MANN, M. E., RESEGHETTI, F., SIMONCELLI, S., GOURETSKI, V., CHEN, G., MISHONOV, A., REAGAN, J. \& ZHU, J. 2021. Upper ocean temperatures hit record high in 2020. Advances in Atmospheric Sciences, 38, 523-530, DOI: https://doi.org/10.1007/s00376-021-0447-x

COLELLA, S., FALCINI, F., RINALDI, E., SAMMARTINO, M. \& SANTOLERI, R. 2016. Mediterranean ocean colour chlorophyll trends. PloS One, 11(6), e0155756.

COM (Commission Report to the Council and the European Parliament). 2014. The first phase of implementation of the Marine Strategy Framework Directive (2008/56/EC) - The European Commission's assessment and guidance. Brussels: Commission Report to the Council and the European Parliament.

CRAMER, W., GUIOT, J., FADER, M., GARRABOU, J., GATTUSO, J. P., IGLESIAS, A., LANGE, M. A., LIONELLO, P., LLASAT, M. C., PAZ, S., PEÑUELAS, J., SNOUSSI, M., TORETI, A., TSIMPLIS, M. N. \& XOPLAKI, E. 2018. Climate change and interconnected risks to sustainable development in the Mediterranean. Nature Climate Change, 8(11), 972-980.

DANOVARO, R., FANELLI, E., CANALS, M., CIUFFRADI, T., FABRI, M. C., TAVIANI, M., ARGYROU, M., AZZURRO, E., BIANCHELLI, S., CANTAFARO, A., CAGURATI, L., CORINALDESI, C., DE HAAN, W. P., DELL'ANNO, A., EVANS, J., FOGLINI F., GALIL, B., GIANNI, M., GOREN, M., GRECO, S., GRIMALT, J., GUELL-BUJUONS, Q., JADUAD, A., KNITTWEIS, L., LOPEZ, J. L., SANCHEZ-VIDAL, A., SCHEMBRI, P. J., SNELGROVE, P. \& VAZ, S. 2020. Towards a marine strategy for the deep Mediterranean Sea: analysis of current ecological status. Marine Policy, 112, 103781, DOI: https://doi.org/10.1016/j.marpol.2019.103781 
DAVIDSON, L. N. \& DULVY, N. K. 2017. Global marine protected areas to prevent extinctions. Nature Ecology \& Evolution, $1(2), 40$.

DULVY, N. K., FOWLER, S. L., MUSICK, J. A., CAVANAGH, R. D., KYNE, P. M., HARRISON, L. R., CARLSON, J. K., DAVIDSON, L. N., FORDHAM, S. V., FRANCIS, M. P. \& POLLOCK, C. M. 2014. Extinction risk and conservation of the world's sharks and rays. eLife, 3, e00590.

EC (European Commission). 2012. Green Paper. Marine knowledge 2020 - from seabed mapping to ocean forecasting. Luxembourg: Publications Office of the European Union.

EC (European Commission). 2015. BLUEMED Research and innovation initiative for blue jobs and growth in the Mediterranean area. Strategic research and innovation agenda. Brussels: European Commission.

EC (European Commission). 2020. The EU blue economy report. Luxembourg: Publications Office of the European Union.

EEA (European Environment Agency). Directive 2014/89/EU Maritime spatial planning [online]. Brussels: European Environment Agency. Available at: https://www.eea.europa.eu/ policy-documents/directive-2014-89-eu-maritime [Accessed: March 2021].

ELBARASSI, H., BASHIR, A. E. \& AZZURRO, E. 2014. Fistularia commersonii Rüppell, 1838 in the Mediterranean Sea: filling the Libyan gap. Journal of Applied Ichthyology, 30(5), 1047-1049.

EPARKHINA, D., POMARO, A., KOULOURI, P., BANCHI, E., CANU, D., UYARRA, M. \& BURKEN, N. 2021. Ocean literacy in European oceanographic agencies: EuroGOOS recommendations for the UN decade of ocean science for sustainable development 2021-2030. Belgium: Publications EuroGOOS, DOI: http://dx.doi.org/10.25607/OBP-1076

EU (European Union). 2019. DIRECTIVE (EU) 2019/904 OF THE EUROPEAN PARLIAMENT AND OF THE COUNCIL of 5 June 2019 on the reduction of the impact of certain plastic products on the environment. Luxembourg: European Union.

EU (European Union). European Commission. DirectorateGeneral for Research and Innovation. 2020. Mission Starfish 2030: restore our ocean and waters - report of the mission board healthy oceans, seas, coastal and inland waters. Luxembourg: European Union.

FALCINI, F., CORRADO, R., TORRI, M., MANGANO, M. C., ZARRAD, R., DI CINTIO, A., PALATELLA, L., JARBOUI, O., MISSAOUI, H., CUTTITTA, A., PATTI, B., SANTOLERI, R., SARÀ, G. \& LACORATA, G. 2020. Seascape connectivity of European anchovy in the Central Mediterranean Sea revealed by weighted Lagrangian backtracking and bio-energetic modelling. Scientific Report, 10, 18630, DOI: https://doi.org/10.1038/s41598020-75680-8

FANELLI, E., AGUZZI, J., MARINI, S., DEL RIO, J., NOGUERAS, M., CANESE, S., STEFANNI, S., DANOVARO, R. \& CONVERSANO, F. 2020. Towards Naples ecological research for augmented observatories (NEREA): the NEREA-Fix module, a standalone platform for long-term deep-sea ecosystem monitoring. Sensors, 20(10), 2911, DOI: https://doi.org/10.3390/ s20102911

FAO (Food and Agriculture Organization of the United Nations). 2020. The State of Mediterranean and Black Sea Fisheries 2020. General Fisheries Commission for the Mediterranean. Rome: Food and Agriculture Organization of the United Nations.
FASSONI-ANDRADEL, A. C., DURANDL, F., MOREIRA, D., AZEVEDO, A., SANTOS, V. F., FUNI, C. \& LARAQUE, A. 2021. Comprehensive bathymetry and intertidal topography of the Amazon estuary. Earth System Science Data, 13(5), 2275-2291, DOI: https://doi.org/10.5194/essd-13-2275-2021

FRANCOCCI, F., PAIFELMAN, E., CIAPPI, E., CEDRE, A., LE CORFF, C. RUEL, C., EFSTRATIOU, C., FALINI, G., GIANNAKOUROU, A., SOLANO-LOPEZ, J. M., STROGYLOUDI, E., RADDADI, N., PISTOCCHI, R., VALENTINI, S. \& BARBANTI, A. 2019. MISTRAL Blue Growth Book. State of the art assessment and overview on the most relevant drivers and opportunities in the Mediterranean Blue Economy [online]. Rome: MISTRAL project. Available at: https://interregmed.eu/fileadmin/user_upload/Sites/Blue_Growth/Projects/ MISTRAL/blue_book_v5_low_res.pdf [Accessed: March 2021].

GALASSI, G. \& SPADA, G. 2014. Sea-level rise in the Mediterranean Sea by 2050: roles of terrestrial ice melt, steric effects and glacial isostatic adjustment. Global and Planetary Change, 123, 55-66.

GARCÉS, E. \& CAMP, J. 2012. Habitat changes in the Mediterranean Sea and the consequences for harmful algal blooms formation. In: STAMBLER, N. (ed.). Life in the Mediterranean Sea: a look at habitat changes. New York: Nova Science Publishers, Inc., pp. 519-541.

GARCÉS, E., MASÓ, M. \& CAMP, J. 1999. A recurrent and localized dinoflagellate bloom in Mediterranean beach. Journal of Plankton Research, 21(12), 2373-2391.

GARCÉS, E., VILA, M., MASÓ, M. \& CAMP, J. 2003. Harmful algae blooms in the Mediterranean Sea, the Catalan coast as an example. In: RODRIGUEZ-PRIETO, C. \& PARDINI, G. (eds.). The Mediterranean Sea. An overview of its present state and plans for future protection. Girona: Servei de Publicacions de la Universitat de Girona, pp. 147-160.

GASCUEL, D., COLL, M., FOX, C., GUÉNETTE, S., GUITTON, J., KENNY, A., KNITTWEIS, L., NIELSEN, J. R., PIET, G., RAID, T. \& TRAVERS-TROLET, M. 2016. Fishing impact and environmental status in European seas: a diagnosis from stock assessments and ecosystem indicators. Fish and Fisheries, 17(1), 31-55.

GIORGETTI, A., PARTESCANO, E., BARTH, A., BUGA, L., GATTI, J., GIORGI, G., IONA, A., LIPIZER, M., HOLDSWORTH, N., LARSEN, M. M., SCHAAP, D., VINCl, M., \&WENZER, M. 2018. EMODnet chemistry spatial data infrastructure for marine observations and related information. Ocean \& Coastal Management, 166, 9-17, DOl: https://doi.org/10.1016/j.ocecoaman.2018.03.016

GONZÁLEZ, D., COUGHLAN, C., STIPS, A., STOLK, A., POLA, C. G., ARANDA, I. M. M., GIORGI, G., REES, J., BABBINI, L., ZEICHEN, M. M., ALENIUS, P., CARIOU, V., ZERVAKIS, V. \& KRZYMINSKI, W. 2015. Review of the Commission Decision 2010/477/EU concerning MSFD criteria for assessing Good Environmental Status. Luxembourg: Joint Research Centre - EU (European Commission), DOI: https://doi.org/10.2788/435059

GUIDETTI, P., NOTARBARTOLO-DI-SCIARA, G. \& AGARDY, T. 2013. Integrating pelagic and coastal MPAs into large-scale ecosystem-wide management. Aquatic Conservation: Marine and Freshwater Ecosystems, 23(1), 179-182.

HERRERA-GARCÍA, G., EZQUERRO, P., TOMÁS, R., BÉJARPIZARRO, M., LÓPEZ-VINIELLES, J., ROSSI, M., MATEOS, R. M., CARREÓN-FREYRE, D., LAMBERT, J., TEATINI, P., CABRAL-CANO, E., ERKENS, G., GALLOWAY, D., HUNG, W. C., KAKAR, N., SNEED, M., TOSI, L., WANG, H. \& YE, S. 2021. Mapping the global threat of land subsidence. Science, 371(6524), 34-36, DOI: https://doi.org/10.1126/science.abb8549 
HOEGH-GULDBERG, O., POLOCZANSKA, E. S., SKIRVING, W. \& DOVE, S. 2017. Coral reef ecosystems under climate change and ocean acidification. Frontiers in Marine Science, 4, 158.

HOWE, B. M., ARBIC, B. K., AUCAN, J., BARNES, C. R., BAYLIFF, N., BECKER, N., BUTLER, R., DOYLE, L., ELIPOT, S., JOHNSON, G. C., LANDERER, F., LENTZ, S., LUTHER, D. S., MÜLLER, M., MARIANO, J., PANAYOTOU, K., ROWE, C., OTA, H., SONG, Y. T., THOMAS, M., THOMAS, P. N., THOMPSON, P., TILMANN, F., WEBER, T. \& WEINSTEIN, S. 2019. SMART cables for observing the global ocean: science and implementation. Frontiers in Marine Science, 6, 424, DOI: https://doi.org/10.3389/fmars.2019.00424

IOC (International Oceanographic Commission of UNESCO). 2020a. United Nations Decade of Ocean Science for Sustainable Development 2021-2030, Implementation Plan, Version 2.0 [online]. Paris: International Oceanographic Commission. Available at: https:// oceanexpert.org/document/27347 [Accessed: March 2021]

IOC (Intergovernmental Oceanographic Commission of UNESCO). 2020b. Global Ocean Science Report 2020 - charting capacity for ocean sustainability [online]. Paris: UNESCO Publishing. Available at: https://unesdoc.unesco.org/ark:/48223/pf0000375147 [Accessed: February 2021]

IOC (International Oceanographic Commission of UNESCO). 2021. Engaging and empowering regional stakeholders synthesis of regional consultation workshops (preparation phase 2019-2020) [online]. Paris: UNESCO Publishing. Available at: https://www. oceandecade.org/resource/140/Engaging-and-Empowering-Regional-Stakeholders-Synthesis-of-Regional-Consultation-Workshops-Preparation-Phase-20192020 [Accessed: July 2021]

JENKINS, T. L. \& STEVENS, J. R. 2018. Assessing connectivity between MPAs: selecting taxa and translating genetic data to inform policy. Marine Policy, 94, 165-173.

KAAL, J., SERRANO, O., CORTIZAS, A. M., BALDOCK, J. A. \& LAVERY, P. S. 2019. Millennial-scale changes in the molecular composition of Posidonia australis seagrass deposits: implications for blue carbon sequestration. Organic Geochemistry, 137, 103898.

KANG-HYUN, J. 2019. Oceanic heritage, ocean literacy, and the way to the future. Journal of Ocean \& Culture, 2, 6-20, DOl: https://doi. org/10.33522/joc.2019.2.6

KANNEN, A., GEE, K., BLAZAUSKAS, N., CORMIER, R., DAHL, K., GÖKE, C., MORF, A., ROSS, A. \& SCHULTZ-ZEHDEN, A. 2016. Bonus Baltspace Deliverable 3.2: a catalogue of approaches and tools for MSP. Luxembourg: EU (European Commission).

KELLY, R., FLEMING, A., PECL, G. T., VON GÖNNER, J. \& BONN, A. 2020. Citizen science and marine conservation: a global review. Philosophical Transactions of the Royal Society B: Biological Sciences, 375(1814), 20190461. DOl: https://doi.org/10.1098/ rstb.2019.0461

LANDRIGAN, P. J., STEGEMAN, J. J., FLEMING, L. E., ALLEMAND, D., ANDERSON, D. M., BACKER, L. C., BRUCKER-DAVIS, F., CHEVALIER, N., CORRA, L., CZERUCKA, D., BOTTTEIN, M. Y. D., DEMENEIX, B., DEPLEDGE, M., DEHEYN, D. D., DORMAN, C. J., FÉNICHEL, P., FISHER, S., GAILL, F., GALGANI, F., GAZE, W. H., GIULIANO, L., GRANDJEAN, P., HAHN, M. E., HAMDOUN, A., HESS, P., JUDSON, B., LABORDE, A., MCGLADE, J., MU, J., MUSTAPHA, A., NEIRA, M., NOBLE, R. T., PEDROTTI, M. L., REDDY, C., ROCKLÖV, J., SCHARLER, U. M., SHANMUGAM, H., TAGHIAN, G., VAN DE WATER, J. A. J. M., VEZZULLI, L., WEIHE, P., ZEKA, A., RAPS, H. \& RAMPAL, P. 2020. Human health and ocean pollution. Annals of Global Health, 86(1), 151. DOI http://doi.org/10.5334/aogh.2831
LE TRAON, P. Y., REPPUCCI, A., ALVAREZ FANJUL, E., AOUF, L., BEHRENS, A., BELMONTE, M., BENTAMY, A., BERTINO, L., BRANDO, V. E., KREINER, M. B., BENKIRAN, M., CARVAL, T., ClLIBERTI, S. A., CLAUSTRE, H., CLEMENTI, E., COPPINI, G., COSSARINI, G., ALONSO-MUÑOYERRO, M. A., DELAMARCHE, A. DIBARBOURE, G., DINESSEN, F., DREVILLON, M., DRILLET, Y., FAUGERE, Y., FERNÁNDEZ, V., FLEMING, A., GARCIA-HERMOSA, M. I., SOTILLO, M. G., GARRIC, G., GASPARIN, F., GIORDAN, C., GEHLEN, M., GREGOIRE, M. L., GUINEHUT, S., HAMON, M., HARRIS, C., HERNANDEZ, F., HINKLER, J. B., HOYER, J., KARVONEN, J., KAY, S., KING, R., LAVERGNE, T., LEMIEUX-DUDON, B., LIMA, L., MAO, C., MARTIN, M. J., MASINA, S, MELET, A., NARDELLI, B. B., NOLAN, G., PASCUAL, A., PISTOIA, J., PALAZOV, A., PIOLLE, J. F., PUJOL, M. I., PEQUIGNET, A. C., PENEVA, E., GÓMEZ, B. P., PETIT, L. A., VILLEON, L., PINARDI, N., PISANO, A., POULIQUEN, S., REID, R., REMY, E., SANTOLERI, R., SIDDORN, J., SHE, J., STANEVA, J., STOFFELEN, A., TONANI, M., VANDENBULCKE, L., VON SCHUCKMANN, K., VOLPE, G., WETTRE, C. \& ZACHARIOUDAKI, A. 2019. From observation to information and users: the Copernicus marine service perspective. Frontiers in Marine Science, 6, 234, DOI: https:// doi.org/10.3389/fmars.2019.00234

LEMASSON, A. J., FLETCHER, S., HALL-SPENCER, J. M. \& KNIGHTS, A. M. 2017. Linking the biological impacts of ocean acidification on oysters to changes in ecosystem services: a review. Journal of Experimental Marine Biology and Ecology, 492, 49-62.

LIONELLO, P., CAVALERI, L., NISSEN, K. M., PINO, C., RAICICH, F. \& ULBRICH, U. 2012. Severe marine storms in the Northern Adriatic: characteristics and trends. Physics and Chemistry of the Earth, Parts $A / B / C, 40-41,93-105, D O I$ : https://doi.org/10.1016/j.pce.2010.10.002

LIONELLO, P. \& SCARASCIA, L. 2018. The relation between climate change in the Mediterranean region and global warming. Regional Environmental Change, 18(5), 1481-1493.

LIUBARTSEVA, S., COPPINI, G. \& LECCI, R. 2019. Are Mediterranean marine protected areas sheltered from plastic pollution? Marine Pollution Bulletin, 140, 579-587, DOI: https://doi.org/10.1016/j.marpolbul.2019.01.022

MACKENZIE, B., CELLIERS, L., ASSAD, L. P. D. F., HEYMANS, J. J., ROME, N., THOMAS, J., ANDERSON, C., BEHRENS, J., CALVERLEY, M., DESAI, K., DIGIACOMO, P. M., DJAVIDNIA, S. SANTOS, F., EPARKHINA, D., FERRARI, J., HANLY, C., HOUTMAN, B., JEANS, G., LANDAU, L., LARKIN, K., LEGLER, D., LE TRAON, P. Y., LINDSTROM, E., LOOSLEY, D., NOLAN, G., PETIHAKIS, G., PELLEGRINI, J., ROBERTS, Z., SIDDORN, J. R., SMAIL, E., SOUSA-PINTO, I. \& TERRILL, E. 2019. The role of stakeholders in creating societal value from coastal and ocean observations. Frontiers in Marine Science, 6, 137, DOI: https://doi.org/10.3389/fmars.2019.00137

MADRICARDO, F., FOGLINI, F., CAMPIANI, E., GRANDE, V., CATENACCI, E., PETRIZZO, A., KRUSS, A., TOSO, C. \& TRINCARDI, F. 2019. Assessing the human footprint on the sea-floor of coastal systems: the case of the Venice Lagoon, Italy. Scientific Reports, 9, 6615.

MALTA. MedFish Ministerial Declaration. 2017. Ministerial conference on the sustainability of Mediterranean fisheries [online]. Malta: MedFish Ministerial. Available at: https://gfcmsitestorage.blob.core.windows.net/website/ MedFish4Ever/2017-03-30-declaration-malta.pdf [Accessed: March 2021]. 
MARAMAI, A., BRIZUELA, B. \& GRAZIANI, L. 2014. The Euro-mediterranean tsunami catalogue. Annals of Geophysics, 57(4), S0435, DOI: https://doi.org/10.4401/ag-6437

MARCOS, M., CALAFAT, F. M., BERIHUETE, A. \& DANGENDORF, S. 2015. Long-term variations in global sea level extremes. Journal of Geophysical Research: Oceans, 120(12), 81158134, DOI: https://doi.org/10.1002/2015JC011173

MARTÍN, B. M., NOVELLINO, A., VINCI, M., CLAUS, S., CALEWAERT, J. B., VALLIUS, H., SCHMITT, T., PITITTO, A., GIORGETTI, A., ASKEW, N., IONA, S., SCHAAP, D., PINARDI, N., HARPHAM, Q., KATER, B. J., POPULUS, J., SHE, J., PALAZOV, A. V., MCMEEL, O., OSET, P., LEAR, D., MANZELLA, G. M. R., GORRINGE, P., SIMONCELLI, S., LARKIN, K., HOLDSWORTH, N., ARVANITIDIS, C. D., MOLINA, M. E. J., MONTERO, M. M. M., HERMAN, P. M. J. \& HERNANDEZ, F. 2019. The European Marine Observation and Data Network (EMODnet): visions and roles of the gateway to marine data in Europe. Frontiers in Marine Science, 6, 313, DOI: https://doi.org/10.3389/fmars.2019.00313

MASELLI, M. \& TRINCARDI, F. 2013. Man made deltas. Scientific Reports, 3(1), 1926, DOI: https://doi.org/10.1038/srep01926

MCKINLEY, E. \& FLETCHER, S. 2010. Individual responsibility for the oceans? An evaluation of marine citizenship by UK marine practitioners. Ocean Coastal Management, 53(7), 379-84.

MEDECC (Mediterranean Experts on Climate and Environmental Change). 2020. Summary for Policymakers. Climate and environmental change in the Mediterranean basin current situation and risks for the future. In: CRAMER, W. GUIOT, J. \& MARINI, K. (eds.). First Mediterranean assessment report. Marseille: Mediterranean Experts on Climate and Environmental Change.

MELAKU, D. C., SOLIDORO, C., BANDELJ, V., QUATTROCCHI, G., SORGENTE, R., OLITA, A., FAZIOLI L. \& CUCCO, A. 2015. Assessment of oil slick hazard and risk at vulnerable coastal sites. Marine Pollution Bulletin, 94(1-2), 84-95.

MELAKU, D. C., SOLIDORO, C., COSSARINI, G. \& GIORGI, F. 2010. Effect of global change on bivalve rearing activity and the need for adaptive management. Climate Research, 42(1), 1326.

MELE, B. H., RUSSO, L., CROCETTA, F., GAMBI, C., DELL'ANNO, A. DANOVARO, R., GUGLIELMO, R., MUSCO, L., PATTI, F. P., RIGINELLA, E., TANGHERLINI, M., D'ALCALÁ, M. R. \& D'ALELIO, D. 2020. Ecological assessment of anthropogenic impact in marine ecosystems: the case of Bagnoli Bay. Marine Environmental Research, 158, 104953.

MELET, A., TEATINI, P., LE COZANNET, G., JAMET, C., CONVERSI, A., BENVENISTE, J. \& ALMAR, R. 2020. Earth observations for monitoring marine coastal hazards and their drivers. Surveys in Geophysics, 41, 1489-1534, DOI: https://doi. org/10.1007/s10712-020-09594-5

MINNETT, P. J., ALVERA-AZCÁRATE, A., CHIN, T., CORLETT, G., GENTEMANN, C., KARAGALI, I., LI, X., MARSOUIN, A., MARULLO, S., MATURI, E., SANTOLERI, R., SAUX, S. P., STEELE, M. \& VAZQUEZ-CUERVO, J. 2019. Half a century of satellite remote sensing of sea-surface temperature. Remote Sensing of Environment, 233, 111366.

MOKOS, M., CHEIMONOPOULOU, M., KOULOURI, P., PREVIATI, M., REALDON, G., SANTORO, F., MOGIAS, A., BOUBONARI, T., GAZO, M., SATTA, A., IOAKEIMIDIS, C., TOJEIRO, A., CHICOTE, C., PAPATHANASSIOU, M. \& KEVREKIDIS, T. 2020. Mediterranean Sea literacy: when ocean literacy becomes region-specific. Mediterranean Marine Science, 21(3), 592598, DOI: https://doi.org/10.12681/mms.23400
MOLINA, M. E. J., MONTERO, M. C., GALGANI, F., GIORGETTI, A VINCI, M., LE MOIGNE, M. \& BROSICH, A. 2019. EMODnet marine litter data management at Pan-European Scale. Ocean and Coastal Management, 181, 104930. https://doi. org/10.1016/j.ocecoaman.2019.104930

MOLTMANN, T., TURTON, J., ZHANG, H. M., NOLAN, G., GOULDMAN, C., GRIESBAUER, L., WILLIS, Z., PINIELLA, Á. M., BARRELL, S., ANDERSSON, E., GALLAGE, C., CHARPENTIER, E., BELBEOCH, M., POLI, P., REA, A., BURGER, E. F., LEGLER, D. M., LUMPKIN, R., MEINIG, C., O'BRIEN, K., SAHA, K., SUTTON, A., ZHANG, D. \& ZHANG, Y. 2019. A global ocean observing system (GOOS), delivered through enhanced collaboration across regions, communities, and new technologies. Frontiers in Marine Science, 6, 291, DOI: https:// doi.org/10.3389/fmars.2019.00291

ORGANELLI, E., BRICAUD, A., GENTILI, B., ANTOINE, D. \& VELLUCCI, V. 2016. Retrieval of colored detrital matter (CDM) light absorption coefficients in the Mediterranean Sea using field and satellite ocean color radiometry: evaluation of bio-optical inversion models. Remote Sensing of Environment, 186, 297-310.

ORGANELLI, E., CLAUSTRE, H., BRICAUD, A., BARBIEUX, M., UITZ, J., D'ORTENZIO, F. \& DALL'OLMO, G. 2017. Bio-optical anomalies in the World's oceans: An investigation on the diffuse attenuation coefficients for downward irradiance derived from biogeochemical Argo float measurements. Journal of Geophysical Research Oceans, 122(5), 35433564, DOI: https://doi.org/10.1002/2016JC012629

PAZZAGLIA, J., REUSCH, T. B. H., TERLIZZI, A., MARÍN-GUIRAO, L. \& PROCACCINI, G. 2021. Phenotypic plasticity under rapid global changes: the intrinsic force for future seagrasses survival. Evolutionary Applications, 14(2), 1181 1201.

PÉREZ-PORTELA, R., RIESGO, A., WANGENSTEEN, O. S., PALACÍN, C. \& TURON, X. 2020. Enjoying the warming Mediterranean: transcriptomic responses to temperature changes of a thermophilous keystone species in benthic communities. Molecular Ecology, 29(17), 3299-3315.

PIERDOMENICO, M., CASALBORE, D. \& CHIOCCI, F. L. 2019. Massive benthic litter funneled to deep sea by flash-flood generated hyperpycnal flows. Scientific Reports, 9, 5330.

PINARDI, N., SIMONCELLI, S., CLEMENTI, E., MANZELLA, G., MOUSSAT, E., QUIMBERT, E., BLANC, F., VALLADEAU, G., GALANIS, G., KALLOS, G., PATLAKAS, P., REIZOPOULOU, S., KYRIAKIDOU, C., KATARA, I., KOUVADA, D., SKOULIKIDIS, N., GOMEZ-PUJOL, L., VALLESPIR, J., MARCH, D., TINTORE, J., FABI, G., SCARCELLA, G., TASSETTI, A. N., RAICICH, F., CRUZADO, A. \& STYLIANOU, S. 2017. EMODnet MedSea checkpoint second data adequacy report (version 1). Oostende: EMODnet (European Marine Observation and Data Network), DOI: https://doi.org/10.25423/cmcc/medsea_ checkpoint_dar2

PISANO, A., MARULLO, S., ARTALE, V., FALCINI, F., YANG, C., LEONELLI, F. E., SANTOLERI, R. \& NARDELLI, B. B. 2020. New evidence of Mediterranean climate change and variability from sea surface temperature observations. Remote Sensing, 12(1), 132, DOI: https://doi.org/10.3390/rs12010132

POMARO, A., CAVALERI, L. \& LIONELLO, P. 2017. Climatology and trends of the Adriatic Sea wind waves: analysis of a 37-year long instrumental data set. International Journal of Climatology, 37(12), 4237-4250, DOI: https://doi. org/10.1002/joc.5066 
PREVIATI, M., CHEIMONOPOULOU, M., KOULOURI, P., REALDON, G., MOKOS, M., MOGIAS, A., BOUBONARI, T. \& KEVREKIDIS, T. 2018. EMSEA Med: a vibrant network for the diffusion of Ocean Literacy in the Mediterranean region. In: $6^{\text {th }}$ European Marine Science Educators Association (EMSEA) Conference, Newcastle, UK, 2-5 Oct 2018. Newcastle: EMSEA.

QIU, W. \& JONES, P. J. S. 2013. The emerging policy landscape for marine spatial planning in Europe. Marine Policy, 39, 182-190, DOI: https://doi.org/10.1016/j.marpol.2012.10.010

QUERO, G. M., FASOLATO, L., VIGNAROLI, C. \& LUNA, G. M. 2015. Understanding the association of Escherichia coli with diverse macroalgae in the lagoon of Venice. Scientific Reports, 5, 10969, DOI: https://doi.org/10.1038/srep10969

RANDONE, M., DI CARLO, G. \& COSTANTINI, M. 2017. Reviving the economy of the Mediterranean Sea: actions for a sustainable future. Rome: World Wildlife Fund - Mediterranean Marine Initiative.

REALDON, G., CHEIMONOPOULOU, M., KOULOURI, P., MOKOS, M., MOGIAS, BOUBONARI, T., KEVREKIDIS, T., PREVIATI, M., SANTORO, F. \& GAZO, M. 2018. EMSEA Med: birth and development of an initiative aimed at fostering Mediterranean Sea Literacy. EGU2018-17617-1. Vienna: European Geosciences Union General Assembly 2018.

REIMANN, L., VAFEIDIS, A. T., BROWN, S., HINKEL, J. \& TOL, R. S. J. 2018. Mediterranean UNESCO world heritage at risk from coastal flooding and erosion due to sea-level rise. Nature Communications, 9, 4161, DOI: https://doi.org/10.1038/ s41467-018-06645-9

RYABININ, V., BARBIÈRE, J., HAUGAN, P., KULLENBERG, G., SMITH, N., MCLEAN, C., TROISI, A., FISCHER, A., ARICÒ, S., AARUP, T., PISSIERSSENS, P., VISBECK, M., ENEVOLDSEN, H. O. \& RIGAUD, J. 2019. The UN decade of ocean science for sustainable development. Frontiers in Marine Science, 6, 470, DOI: https://doi.org/10.3389/fmars.2019.00470

SALON, S., COSSARINI, G., BOLZON, G., FEUDALE, L., LAZZARI, P., TERUZZI, A., SOLIDORO, C. \& CRISE, A. 2019. Novel metrics based on biogeochemical Argo data to improve the model uncertainty evaluation of the CMEMS Mediterranean marine ecosystem forecasts. Ocean Science, 15, 997-1022, DOI: https://doi.org/10.5194/os-15-997-2019

SAMMARTINO, M., DI CICCO, A., MARULLO, S. \& SANTOLERI, R. 2015. Spatio-temporal variability of micro-, nano-and pico-phytoplankton in the Mediterranean Sea from satellite ocean colour data of SeaWiFS. Ocean Science, 11(5), 759778.

SAMMARTINO, M., NARDELLI, B. N., MARULLO, S. \& SANTOLERI, R. 2020. An artificial neural network to infer the Mediterranean 3D chlorophyll-a and temperature fields from remote sensing observations. Remote Sensing, 12(24), 4123.

SHEPHERD, I. 2018. European efforts to make marine data more accessible. Ethics in Science and Environmental Politics, 18, 75-81, DOI: https://doi.org/10.3354/esep00181

SLOYAN, B. M., WILKIN, J., HILL, K. L., CHIDICHIMO, M. P., CRONIN, M. F., JOHANNESSEN, J. A., KARSTENSEN, J., KRUG, M., LEE, T., OKA, E., PALMER, M. D., RABE, B., SPEICH, S., VON SCHUCKMANN, K., WELLER, R. A. \& YU, W. 2019. Evolving the physical global ocean observing system for research and application services through international coordination. Frontiers in Marine Science, 6, 449, DOI https://doi. org/10.3389/fmars.2019.00449
SOLIDORO, C., BANDELJ, V., COSSARINI, G., LIBRALATO, S. \& CANU, D. M. 2009. Challenges for ecological modelling in a changing world: global changes, sustainability and ecosystem based management. Ecological Modelling, 21(220), 2825-2827.

SPROVIERI, M., CORI, L., BIANCHI, F., CIBELLA, F. \& GAETANO, A. 2021. Ambiente e salute nei siti contaminati. Rome: Dalla Ricerca Scientifica Alle Decisioni.

SPROVIERI, M., ELJARRAT, E. \& BIANCHI, F. 2020. Editorial: environment and health. Frontiers in Earth Science, 8, 598611, DOI: https://doi.org/10.3389/feart.2020.598611

STUCHTEY, M., VINCENT, A., MERKL, A. \& BUCHER, M. 2020. Ocean solutions that benefit people, nature and the economy [online]. Washington, DC: World Resources Institute. Available at: www.oceanpanel.org/ocean-solutions [Accessed: July 2021].

TANHUA, T., POULIQUEN, S., HAUSMAN, J., O'BRIEN, K., BRICHER, P., DE BRUIN, T., BUCK, J. J. H., BURGER, E. F., CARVAL, T., CASEY, K. S., DIGGS, S., GIORGETTI, A., GLAVES, H., HARSCOAT, V., KINKADE, D., MUELBERT, J. H., NOVELLINO, A., PFEIL, B., PULSIFER, P. L., VAN DE PUTTE, A., ROBINSON, E., SCHAAP, D., SMIRNOV, A., SMITH, N., SNOWDEN, D., SPEARS, T., STALL, S., TACOMA, M., THIJSSE, P., TRONSTAD, S., VANDENBERGHE, T., WENGREN, M., WYBORN, L. \& ZHAO, Z. 2019. Ocean FAIR data services. Frontiers in Marine Science, 6, 440, DOI: https:// doi.org/10.3389/fmars.2019.00440

TERZIĆ, E., LAZZARI, P., ORGANELLI, E., SOLIDORO, C., SALON, S., D'ORTENZIO, F. \& CONAN, P. 2019. Merging bio-optical data from Biogeochemical-Argo floats and models in marine biogeochemistry. Biogeosciences, 16(12), 2527-2542, DOI: https://doi.org/10.5194/bg-16-2527-2019

TINTORÉ, J., PINARDI, N., ÁLVAREZ-FANJUL, E., AGUIAR, E., ÁLVAREZ-BERASTEGUI, D., BAJO, M., BALBIN R., BOZZANO, R., NARDELLI, B. B., CARDIN, V., CASAS, B., CHARCOSLLORENS, M., CHIGGIATO, J., CLEMENTI, E., COPPINI, G., COPPOLA, L., COSSARINI, G., DEIDUN, A., DEUDERO, S., D'ORTENZIO, F., DRAGO, A., DRUDI, M., EL SERAFY, G., ESCUDIER, R., FARCY, P., FEDERICO, I., FERNÁNDEZ, J. G., FERRARIN, C., FOSSI, C., FRANGOULIS, C., GALGANI, F., GANA, S., LAFUENTE, J. G., SOTILLO, M. G., GARREAU, P., GERTMAN, I., GÓMEZ-PUJOL, L., GRANDI, A., HAYES, D., HERNÁNDEZ-LASHERAS, J., HERUT, B., HESLOP, E., HILMI, K., JUZA, M., KALLOS, G., KORRES, G., LECCI, R., LAZZARI, P., LORENTE, P., LIUBARTSEVA, S., LOUANCHI, F., MALACIC, V., MANNARINI, G., MARCH, D., MARULLO, S., MAURI, E., MESZAROS, L., MOURRE, B., MORTIER, L., MUÑOZ-MAS, C., NOVELLINO, A., OBATON, D., ORFILA, A., PASCUAL, A., PENSIERI, S., PÉREZ-GÓMEZ, B., PÉREZ-RUBIO, S., PERIVOLIOTIS, L., PETIHAKIS, G., DE LA VILLÉON, L. P., PISTOIA, J., POULAIN, P. M., POULIQUEN, S., PRIETO, L., RAIMBAULT, P., REGLERO, P., REYES, E., ROTLLAN, P., RUIZ, S., RUIZ, J., RUIZ, I., RUIZ-OREJÓN, L. F., SALIHOGLU, B., SALON, S., SAMMARTINO, S., ARCILLA, A. S., SÁNCHEZ-ROMÁN, A., SANNINO, G., SANTOLERI, R., SARDÁ, R., SCHROEDER, K., SIMONCELLI, S., SOFIANOS, S., SYLAIOS, G., TANHUA, T., TERUZZI, A., TESTOR, P., TEZCAN, D., TORNER, M., TROTTA, F., UMGIESSER, G., VON SCHUCKMANN, K., VERRI, G., VILIBIC, I., YUCEL, M., ZAVATARELLI, M. \& ZODIATIS, G. 2019. Challenges for sustained observing and forecasting systems in the Mediterranean Sea. Frontiers in $\mathrm{Ma}$ rine Science, 6, 568 . 
TODD, P. A., HEERY, E. C., LOKE, L. H., THURSTAN, R. H., KOTZE, D. J. \& SWAN, C. 2019. Towards an urban marine ecology: characterizing the drivers, patterns and processes of marine ecosystems in coastal cities. Oikos, 128(9), 1215-1242.

TONINI, R., DI MANNA, P., LORITO, S., SELVA, J., VOLPE, M., ROMANO, F., BASILI, R., BRIZUELA, B., CASTRO, M. J., DE LA ASUNCIÓN, M., DI BUCCI, D., DOLCE, M., GARCIA, A., GIBBONS, S. J., GLIMSDAL, S., GONZÁLEZ-VIDA, J. M., LØVHOLT, F., MACÍAS, J., PIATANESI, A., PIZZIMENTI, L., SÁNCHEZ LINARES, C. \& VITTORI, E. 2021. Testing inundation maps for evacuation planning in Italy. Frontiers in Earth Science, 9, 628061, DOI: https://doi.org/10.3389/feart.2021.628061

TRABONI, C., MAMMOLA, S. D., RUOCCO, M., ONTORIA, Y., RUIZ, J. M., PROCACCINI, G. \& MARÍN-GUIRAO, L. 2018. Predictive molecular indicators of heat stress in the seagrass Posidonia oceanica in a global change scenario. Marine Environmental Research, 141, 12-23.

TRIANTAFYLLOU, I., GOGOU, M., MAVROULIS, S., LEKKAS, E., PAPADOPOULOS, G. A. \& THRAVALOS, M. 2021. The tsunami caused by the 30 October 2020 Samos (Aegean Sea) Mw7.0 Earthquake: hydrodynamic features, source properties and impact assessment from post-event field survey and video records. Journal of Marine Science and Engineering, 9(1), 68, DOI: https://doi.org/10.3390/jmse9010068

TRINCARDI, F., BARBANTI, A., BASTIANINI, M., BENETAZZO, A. CAVALERI, L., CHIGGIATO, J., PAPA, A., POMARO, A., SCLAVO, M., TOSI, L. \& UMGIESSER, G. 2016. The 1966 flooding of Venice: what time taught us for the future. Oceanography, 29(4), 178-186.

TUNESI, L., CASAZZA, G., DALÙ, M. \& GIORGI, G. 2013. The implementation of the marine strategy framework directive in Italy: knowledge to support the management. Biologia Marina Mediterranea, 20(1), 35-52.

UMGIESSER, G. 2020. The impact of operating the mobile barriers in Venice (MOSE) under climate change. Journal for Nature Conservation, 54, 125783, DOI: https://doi. org/10.1016/j.jnc.2019.125783

UNEP (DEPI)/MED (United Nations Environment Programme/ Mediterranean Action Plan). 2008. Decision IG 17/6: Implementation of the ecosystem approach to the management of human activities that may affect the Mediterranean marine and coastal environment [online]. Athens: United Nations Environment Programme/Mediterranean Action Plan. Available at: https://www.rac-spa.org/sites/default/files/ecap/ ig17_6_eng.pdf [Accessed: July 2021]

UNEP (DEPI)/MED (United Nations Environment Programme/ Mediterranean Action Plan). 2012. Decision IG.20/4 Implementing MAP ecosystem approach roadmap: Mediterranean ecological and operational objectives, indicators and timetable for implementing the ecosystem approach roadmap [online]. Paris: United Nations Environment Programme/ Mediterranean Action Plan. Available at: https://wedocs. unep.org/bitstream/handle/20.500.11822/7320/12ig20_8_ annex2_20_04_eng.pdf [Accessed: February 2021]

UNEP (DEPI)/MED (United Nations Environment Programme/ Mediterranean Action Plan). 2013. Decision IG.21/3 on the ecosystems approach including adopting definitions of good environmental status (GES) and targets [online]. Istanbul: United Nations Environment Programme/Mediterranean Action Plan. Available at: https://wedocs.unep. org/bitstream/handle/20.500.11822/6008/13ig21_09_annex2_21_03_eng.pdf [Accessed: March 2021]
UNEP/MAP (United Nations Environment Programme/Mediterranean Action Plan). 2015. Marine litter assessment in the Mediterranean. Barcelona: United Nations Environment Programme/ Mediterranean Action Plan - Barcelona Convention.

UNEP/MAP (United Nations Environment Programme/Mediterranean Action Plan). 2017. Mediterranean quality status report (QSR). Barcelona: United Nations Environment Programme/ Mediterranean Action Plan - Barcelona Convention.

UNEP/MAP (United Nations Environment Programme/Mediterranean Action Plan). Plan Bleu Regional Activity Centre. 2020 SoED 2020: state of environment and development in Mediterranean [online]. Marseille: United Nations Environment Programme/Mediterranean Action Plan \& Plan Bleu Regional Activity Centre. Available at: https://planbleu.org/wp-content/uploads/2020/11/SoED-Full-Report.pdf [Accessed: March 2021]

VALENTINI, A., TABERLET, P., MIAUD, C., CIVADE, R., HERDER, J., THOMSEN, P. F., BELLEMAIN, E., BESNARD, A., COISSAC, E., BOYER, F., GABORIAUD, C., JEAN, P., POULET, N., ROSET, N., COPP, G. H., GENIEZ, P., PONT, D., ARGILLIER, C., BAUDOIN, J. M., PEROUX, T., CRIVELLI, A. J., OLIVIER, A., ACQUEBERGE, M., LE BRUN, M., MØLLER, P. R., WILLERSLEV, E. \& DEJEAN, T. 2016. Next-generation monitoring of aquatic biodiversity using environmental DNA metabarcoding. Molecular Ecology, 25(4), 929-42, DOI: https://doi.org/10.1111/mec.13428

VOLPE, G., COLELLA, S., FORNERIS, V., TRONCONI, C. \& SANTOLERI, R. 2012. Mediterranean ocean colour observing system - system development and product validation. Ocean Science, 8(5), 869883, DOI: https://doi.org/10.5194/os-8-869-2012

VON SCHUCKMANN, K., LE TRAON, P. Y., SMITH, N., PASCUAL, A., DJAVIDNIA, S., GATTUSO, J. P., GRÉGOIRE, M., NOLAN, G., AABOE, S., FANJUL, E. Á., AOUF, L., AZNAR, R., BADEWIEN, T. H., BEHRENS, A., BERTA, M., BERTINO, L., BLACKFORD, J., BOLZON, G., BORILE, F., BRETAGNON, M., BREWIN, R. J.W., CANU, D., CESSI, P., CIAVATTA, S., CHAPRON, B., TRANG CHAU, T. T., CHEVALLIER, F., CHTIRKOVA, B., CILIBERTI, S., CLARK, J. R., CLEMENTI, E., COMBOT, C., COMERMA, E., CONCHON, A., COPPINI, G., CORGNATI, L. P., COSSARINI, G., CRAVATTE, S., DE ALFONSO, M., DE BOYER MONTÉGUT, C., DE LERA, FERNÁNDEZ, C., DE LOS SANTOS, F. J., DENVIL-SOMMER, A., DE PASCUAL COLLAR, Á., DIAS NUNES, P. A. L., DI BIAGIO, V., DRUDI, M., EMBURY, O., FALCO, P., D'ANDON, O. F., FERRER, L., FORD, D., FREUND, H., LEÓN, M. G., SOTILLO, M. G., GARCÍA-VALDECASAS, J. M., GARNESSON, P., GARRIC, G., GASPARIN, F., GEHLEN, M., GENUA-OLMEDO, A., GEYER, G., GHERMANDI, A., GOOD, S. A., GOURRION, J., GREINER, E., GRIFFA, A., GONZÁLEZ, M., HERNÁNDEZ-CARRASCO, I., ISOARD, , S., KENNEDY, J. J., KAY, S., KOROSOV, A., LAANEMÄE, K., LAND, P. E., LAVERGNE, T., LAZZARI, P., LEGEAIS, J. F., LEMIEUX,"B., LEVIER, B., LLOVEL, W., LYUBARTSEV, V., LIEN, V. S., LIMA, L., LORENTE, P., MADER, J., MAGALDI, M. G., MANGIN, A., MALJUTENKO, I., MANTOVANI, C., MARINOVA, V., MASINA, S., MAURI, E., MEYERJÜRGENS, J., MIGNOT, A., MCEWAN, R., MEJIA, C., MELET, A., MENNA, M., MEYSSIGNAC, B., MOUCHE, A., MOURRE, B., MÜLLER, M., NOTARSTEFANO, G., PARDO, S., ORFILA, A., PENEVA, E., PÉREZ-GÓMEZ, B., PERRUCHE, C., PETERLIN, M., POULAIN, P. M., PINARDI, N., QUILFEN, Y., RAUDSEPP, U., RENSHAW, R., RÉVELARD, A., REYES-REYES, E., RICKER, M., RODRÍGUEZ-RUBIO, P., ROTLLÁN, P., GELABERT, E. R., RUBIO, A., RUIZ-PARRADO, I., SATHYENDRANATH, S., SHE, J., VON SCHUCKMANN, K., SOLIDORO, C., STANEV, E. V., STANEVAM, J., STORTOM, A., SUM, J., BAKHSHM, T. T., TILSTONEM, G. H., TINTORÉ, J., TOLEDANO, C., TOURNADREM, J., TRANCHANT, B., UIBOUPIN, R., VALCARCEL, A., VALCHEVA, N., VERBRUGGE, N., VRAC, M., WOLFF, J. O., ZAMBIANCHI, E., ZIELINSKI, O. \& ZUNINO, S. 2020. Copernicus 
marine service ocean state report. Journal of Operational Oceanography, 13(4 Suppl 1), S1-S172, DOI: https://doi.org/10.1080/ 1755876X.2020.1785097

WILKINSON, M. D., DUMONTIER, M., AALBERSBERG, I. J., APPLETON, G., AXTON, M., BAAK, A., BLOMBERG, N., BOITEN, J. W., SANTOS, L. B. S., BOURNE, P. E., BOUWMAN, J., BROOKES, A. J., CLARK, T., CROSAS, M., DILLO, I., DUMON, O., EDMUNDS, S., EVELO, C. T., FINKERS, R., GONZALEZ-BELTRAN, A., GRAY, A. J. G., GROTH, P., GOBLE, C., GRETHE, J. S., HERINGA, J., A.C'T HOEN, P., HOOFT, R., KUHN, T., KOK, R., KOK, J., LUSHER, S. J., MARTONE, M. E., MONS, A., PACKER, A. L., PERSSON, B., ROCCA-SERRA, P., ROOS, M., VAN SCHAIK, R., SANSONE, S. A., SCHULTES, E., SENGSTAG, T., SLATER, T., STRAWN, G., SWERTZ, M. A., THOMPSON, M., VAN DER LEI, J., VAN MULLIGEN, E., VELTEROP, J., WAAGMEESTER, A., WITTENBURG, P., WOLSTENCROFT, K., ZHAO, J. \& MONS, B. 2016. The FAIR guiding principles for scientific data management and stewardship. Scientific Data, 3, 160018, DOI: https://doi. org/10.1038/sdata.2016.18
WOLFF, C., NIKOLETOPOULOS, T., HINKEL, J. \& VAFEIDIS, A. T. 2020. Future urban development exacerbates coastal exposure in the Mediterranean. Scientific Reports, 10, 14420, DOI: https://doi.org/10.1038/s41598-020-70928-9

WWF (World Wildlife Fund). 2019. Stop the flood of plastic: how Mediterranean countries can save their sea. Rome: World Wildlife Fund - Mediterranean Marine Initiative.

ZINGONE, A., ESCALERA, L., ALIGIZAKI, K., FERNÁNDEZ-TEJEDOR, M., ISMAEL, A., MONTRESOR, M., MOZETIČ, P., TAŞ, S. \& TOTTI, C. 2021. Toxic marine microalgae and noxious blooms in the Mediterranean Sea: a contribution to the Global HAB Status Report. Harmful Algae, 102, 101843, DOI: https://doi.org/10.1016/j. hal.2020.101843

ZUNINO, S., LIBRALATO, S., MELAKU, D. C. \& SOLIDORO, C. 2021. Impact of ocean acidification on ecosystem functioning and services in habitat-forming species and marine ecosystems. Ecosystems, 2021, 1-15. 


\section{Erratum}

In the Collective positioning "The Mediterranean Sea we want", with DOI code number: http:// doi.org/10.1590/2675-2824069.21019mc, publicado no periódico Ocean and Coastal Research 2021, v69(suppl):e21031:

\section{Where it was written:}
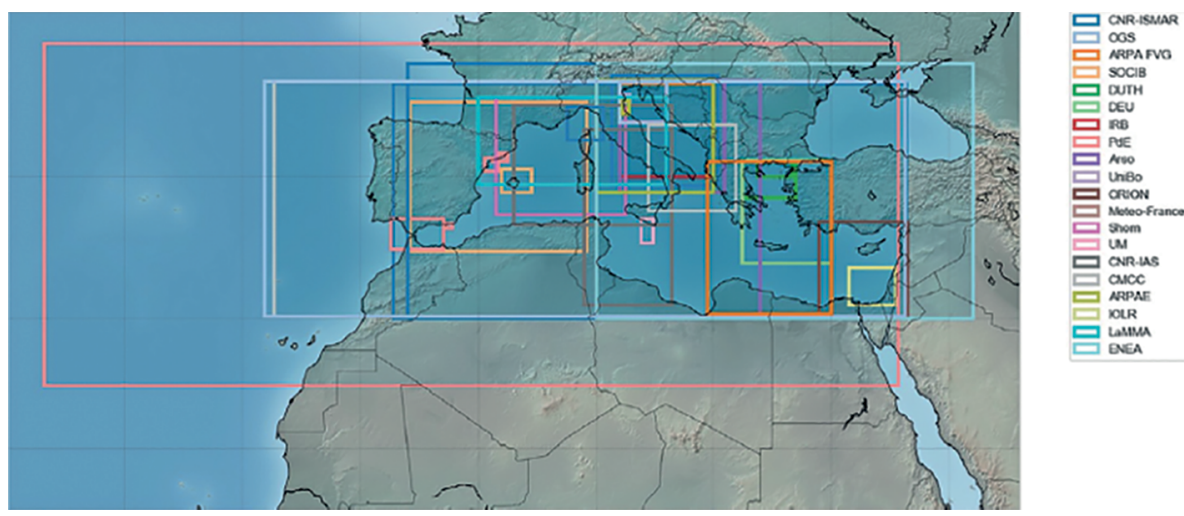

Figure 5. Map of the operational modeling domain of the Mediterranean Sea (Capet et al. 2020).

\section{Should read:}
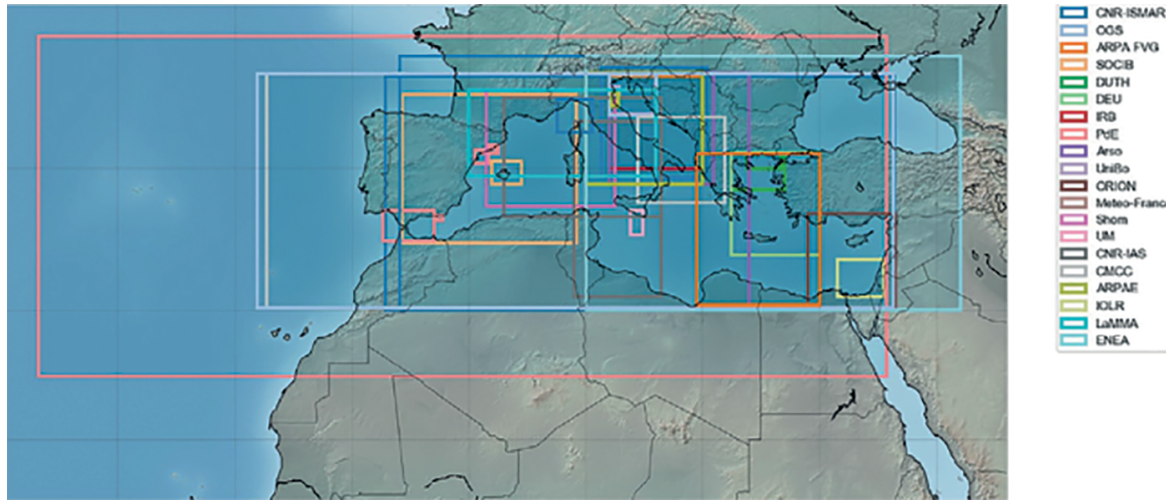

Figure 5. Map of the operational modeling domain of the Mediterranean Sea (modified from Capet et al, 2020). 